\title{
فاعلية برنامج مقتزح لعلاج الصعوبات الإملائية لدى تلاميذ الصف السادس الابتدائي في مدينة نـجران
}

\section{ع}

الملخغص:

استهدفت هذه الدراسة إلى التعرف إلى الصعوبات الإملائية الأكثر شيوعًا لدى تلاميـــ الـصف

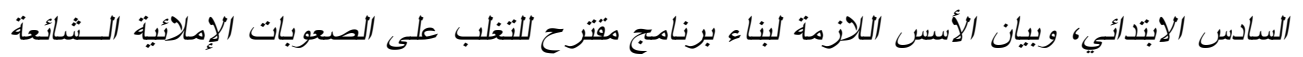

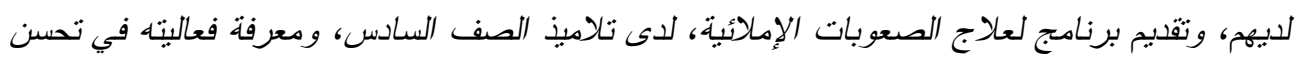

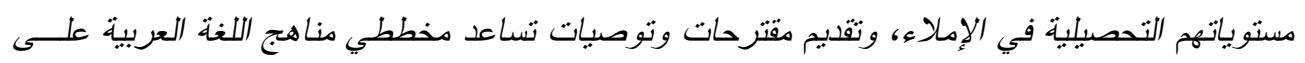
تطوير البرامج والإستراتيجيات التنفيذية؛ لإكساب تلاميذ المرحلة الابتدائية مهارات اللغة العربية، ومنهـاتيات المهارات الإملائية.

وقد توصل الباحث إلى وضع تصور مقترح يعين الباحثين على تثخيص الصعوبات الإملائية التي

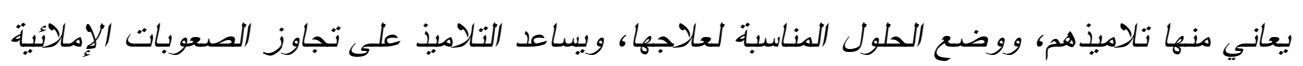
التي كانو ا بتعثرون فيها. وفي ضوء ما أسفرت عنه اللداسة من نتائج فإنها توصي بعا يلي:

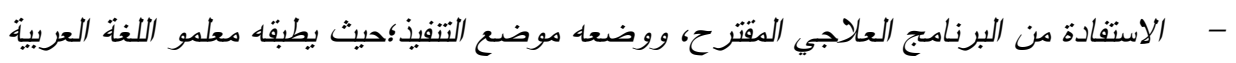

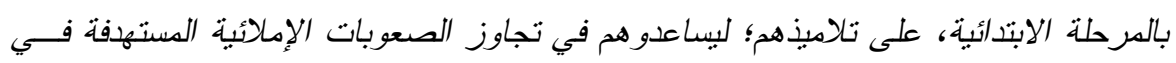

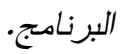
ضرورة إثراك معلمي المو اد الأخرى في تصحيح الأخطاء الإملائية لدى طلابهم؛ تعاوناً منهم

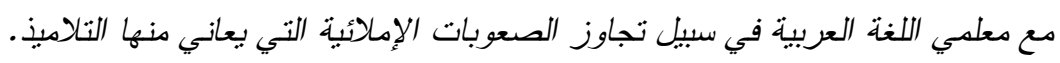

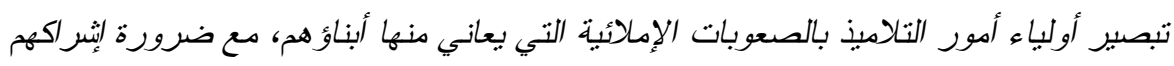
في تنفيذ الخطط العلاجية الخاصة بالأبناء. تجهيز غرف الدراسة في كل مدرسة ابتدائية ومتوسطة بالتقنيات الحديثة من حاسـبـات آليــة، وشاثات عرض، وشبكات اتصال بالانترنت؛ لتوظيفها في التغلب على الصعوبات الإملائيــة

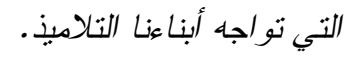




\begin{abstract}
:
This study aimed to identify the most common spelling difficulties in sixth grade primary students, and to explain the foundations necessary to build a proposed program to overcome common spelling difficulties, and to provide a program for the treatment of spelling difficulties among sixth grade students, and know its effectiveness in improving their achievement levels in spelling, and provide Proposals and recommendations help Arabic language curriculum planners develop executive programs and strategies to provide primary school students with Arabic language skills, including spelling skills.

The researcher has come up with a conceptual proposal to help researchers to diagnose the spelling difficulties experienced by their pupils, and to develop appropriate solutions to treat them, and help pupils to overcome the spelling difficulties they were stumbling upon.
\end{abstract}

\title{
In the light of the results of the study, it recommends the following:
}

- Take advantage of the proposed therapeutic program, and put it into practice; where applied by teachers of Arabic language at the primary stage, on their students; to help them overcome the spelling difficulties targeted in the program.

- The need to involve teachers of other subjects in correcting spelling mistakes among their students; in cooperation with them teachers of the Arabic language in order to overcome the spelling difficulties experienced by pupils.

- Enlighten the parents of students with the spelling difficulties experienced by their children, with the need to involve them in the implementation of treatment plans for children.

- Equipping classrooms in every elementary and middle school with modern technologies such as computers, projectors and internet networks to be used to overcome the spelling difficulties facing our pupils.

$$
\begin{aligned}
& \text { إلى تحصيل المعارف و الخبرات (الحــلاق، }
\end{aligned}
$$

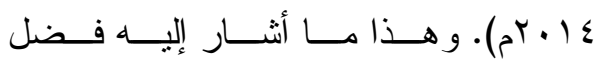

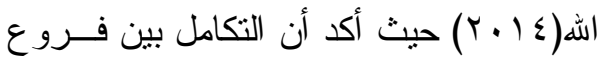

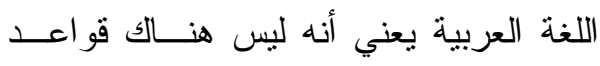

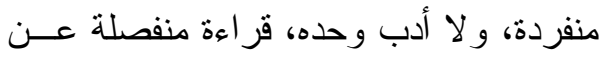

$$
\begin{aligned}
& \text { الإملاء، بل إن التكامل المعرفي يقتضي ربط } \\
& \text { فروع اللغة العربية ببعضها؛ ليحدث نوعـاً }
\end{aligned}
$$

$$
\begin{aligned}
& \text { يحتل الإملاء منزلة كبيرة بين فنــون } \\
& \text { اللغة العربية، وهو من الأسس المهمة للتعبير }
\end{aligned}
$$

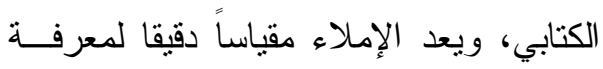

$$
\begin{aligned}
& \text { المستوى التحصيلي الذي وصل إليه التلاميذ }
\end{aligned}
$$

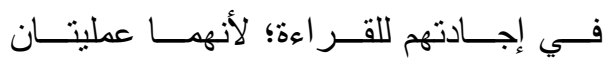

$$
\begin{aligned}
& \text { متلازمتان، إن صح الإملاء صحت القـــــاءة } \\
& \text { و العكس صحيح، وكلاهما يعد مفتاح الدخول }
\end{aligned}
$$


الكتابة وفهم المقرو ء، فكلما قر أ التلميذ أكثـــر

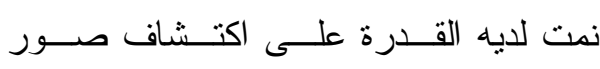

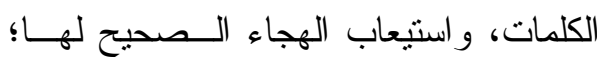

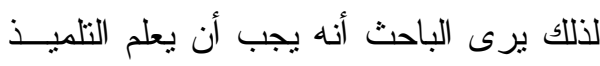

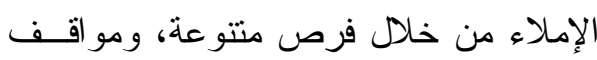

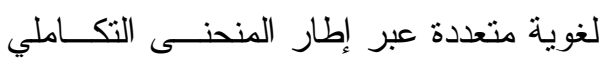
للغة.

وأكدت الكثير من الدر اسات أنه تبعــاً لذلك ظهرت الكثير من الــدعوات للعنايــة بالإملاء، وتلك الدعوات تتجلى في اتجاهات ثلاثة: - مانة

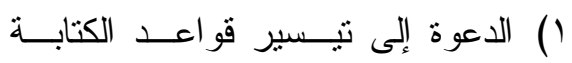
العربية وتوحيــدها، وعقـدت لــــللك

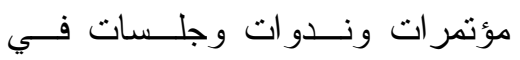
مو اضع متعددة، وأزمان مختلفة. r الدعوة إلى دراسة أسس تعليم الإملاء

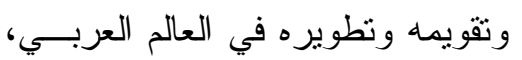
وقد ظهرت هذه الدعوات على شـــل در اسات وكتب مختلفة فــي منـــاهج وطرق تدريس اللغة العربيــة بـشك

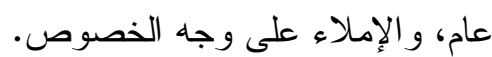
r) الدعوة إلى حصر الأخطاء الإملائيــة ومعالجتها في جميع المراحل الدراسية الإسية

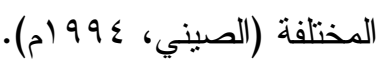
وقد أكدت دراسة الظفيري (r...rم) أن تفشي أخطاء الرسم الكتابي بين طــلاب

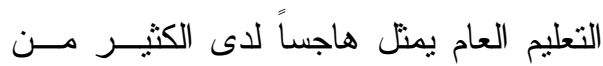

من الانسجام و التز ابط فيما بينها. ومما يجدر التتويه به أن الإملاء في اللغة العربية يمتاز

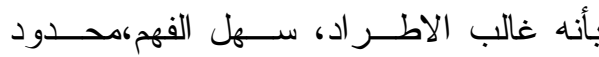

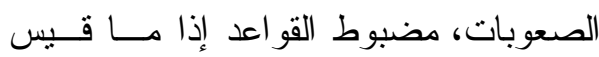

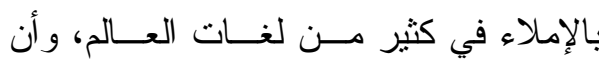

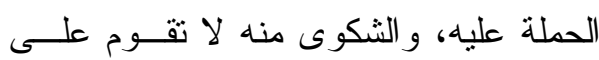

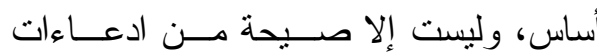
المتجنين على اللغة العربية من حيث آدابها، وقو اعدها الإملائية (إير اهيم، 9 ( )). وتتبع أهمية الإملاء من حيث أنه يعلم

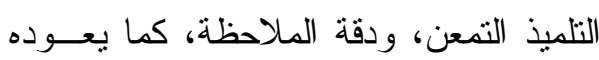

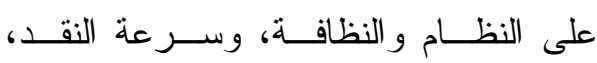

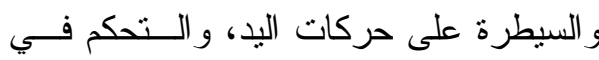
الكتابة، وللإملاء أهمية نفسية عظيمة بالنسبة للتلميذ، فالتلميذ القادر على الكتابة الصحيحة المقرو عة تتكون لديه شخصية مستقلة تجعله

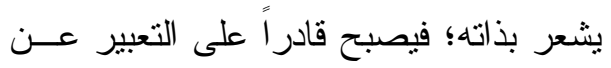

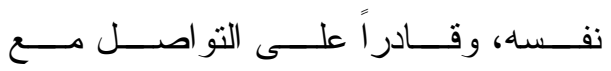
الآخرين (عاشور و الحو امدة، ال المبح). وبانتشار التعليم وغلبة الكتابـــة فـي العصر الحديث بدأت الصعوبات الإملائيــة

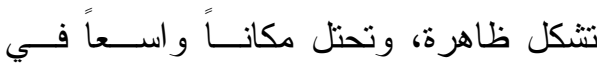

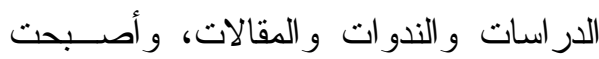
هناك شكوى ملحة من ازدياد هذه الصعوبات ولنات ولنات

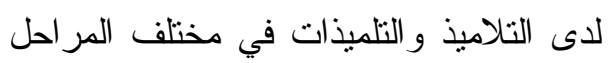
الدراسية، ما أدى إلى نتويه الكتابة، وإعاقة

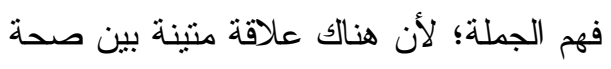


محددة، ولا يوفر فرصاً للفهـم و الاســتخدام و التطبيق في مو اقف مماتلة (عبيدات، وأبــو

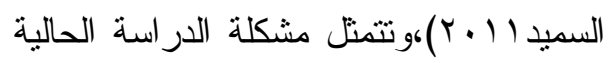

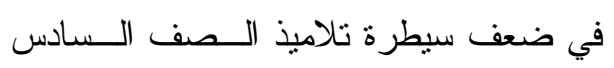

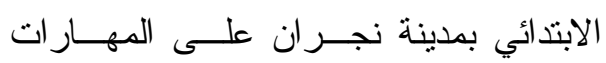
الإملائية الكتابية، ووجود صعوبات كثبــرة

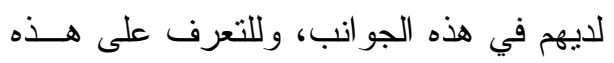
الصعوبات، ومعالجة هذه المشكلة جاءت هذه وله

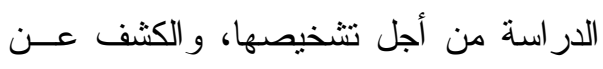
أسبابها، ثم وضع الحلول المناسبة لعلاجها. وللتــصدي لهـــه المـشكلة تحــاول الدراسة الحالية الإجابة عن السؤال الـــئيس الآتي:

ما فاعلية برنــامج مقتــرح لعــلاج

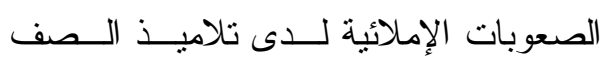
السادس الابتدائي بمدينة نجران؟ ويتفرع عن هذا السؤال الأسئلة التالية: - السؤ ال الأول: ما الصعوبات الإملائيـــة لدى تلاميذ الصف الــسادس الابتـــائي بمدينة نجر ان؟

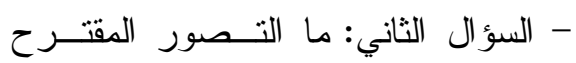
لعلاج الصعوبات الإملائية لدى تلاميذ

$$
\text { الصف السادس الابتدائي؟ }
$$

- السؤال الثالث: ما فاعلية برنامج مقتر ح لعلاج الصعوبات الإملائيـــة المتعلقــــة
التزبويين، و أولياء الأمور ؛ لكونها: تعرقــلـ

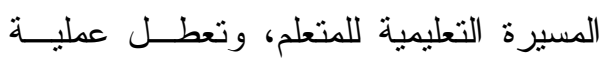

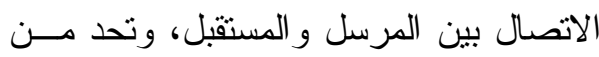

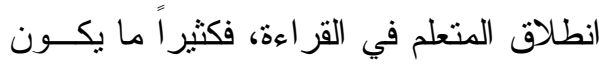
الخطأ في القر اءة سببه خطأ في الكتابة. وتأسيساً على ما تقدم، ونظر اً لمكانـــة

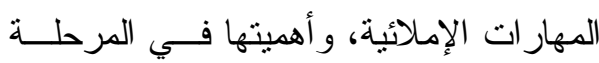

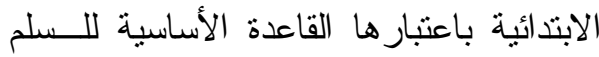
التعليمي، وضـــرورة العهـلـل علـــى تهيئــة المو اقف التعليمية المناسبة التي تـسـاهم فـي وضي تتميتها، وتحد مــن الــصعوبات الإملائيــة الثائعة في كتابات التناميذ، وبحكـم عدـلـل

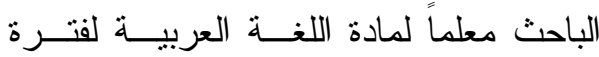

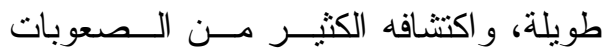

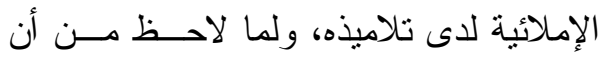

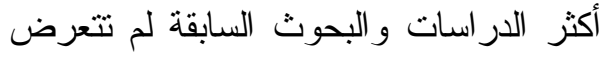
لعلاج تلك الصعوبات الإملائية المسـتهدفة

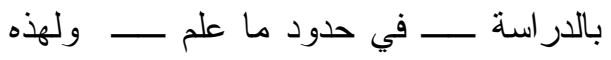
الأسباب مجتمعة بدت للباحث الحاجة ملحــة لإجر اء هذه الدر اسة.

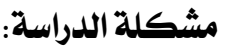

و هي مـشكلة يعـاني منهـــا أغلــب المتعلمين حتى في المر احل المتقدمـــة مثنـل فئل

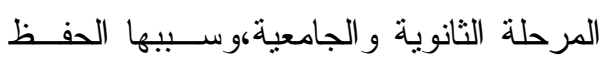
و التلقين، وعدم وضع التلاميذ أمام مشكلات حقيقية، يشعرون بها ويعايشونها؛ لأن التعليم

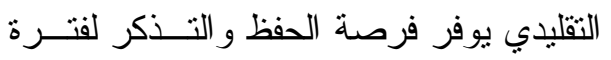


يعاني منها التلاميذ، وخاصة مــشكلة

$$
\text { الضعف اللغوي. }
$$

• إن إجر اء الدراسة الحالية قد يفيد أولياء أمور التلاميذ الذين تقع على عــو اتقهم المسؤولية المبانشرة في منابعة أبنائهم من الناحية الدر اسية.

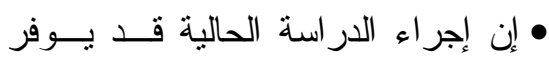
المعلومات الكافية التي تساعد صانعي

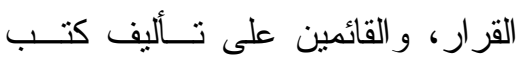
اللغة العربية فــي اتخــاذ القــرارات

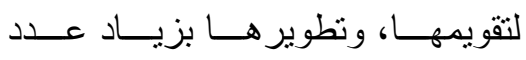

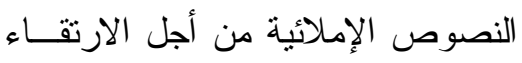

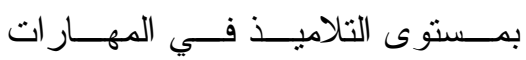
الإملائية إلى المستوى الأفضل. • إعداد اختبار تحصيلي (نص إملائـي)

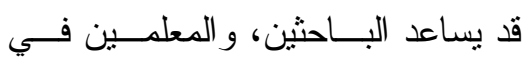

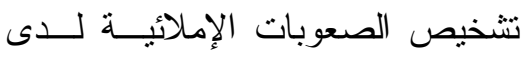
تلاميذهم. • ما تقدمه هذه الدر اسة مــن توصــيات

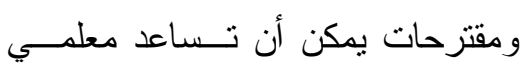

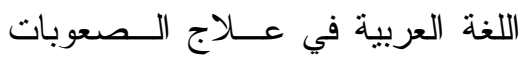
الإملائية لاى تلاميذهم.

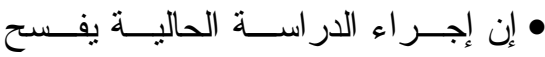
المجال، ويفتح الباب لمزيد من البحوث

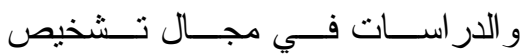
الصعوبات الإملائية، وطرق علاجهــا

$$
\text { و التغلب عليها. }
$$

بالهمزات لدى تلاميذ الصف الـسادس

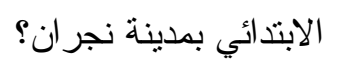

- السؤال الر ابع: ما فاعلية برنامج مقترح

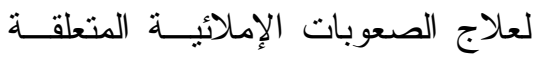
بالحروف لدى تلاميذ الصف الـسادس الابتدائي بمدينة نجر ان؟ تلان

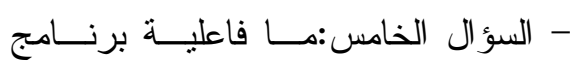

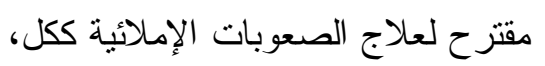

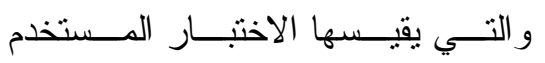
بالدر اسة لدى تلاميذ الــصف الـــادس

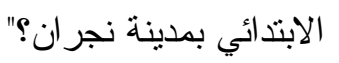
أهمية الدراسة:

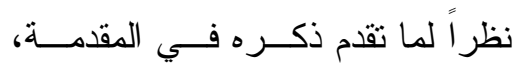
ومشكلة الدراسة، برزت أهمبة إجر اء هــــه

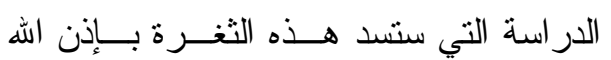
تعالى في مجال المـشكلة المحــدد بحثنهـا، ويأمل الباحث أن تكتسب دراسته هذه أهمية علمية للأسباب الآتية: • الدراسة الحالية تتتاول مهار ات الإملاء

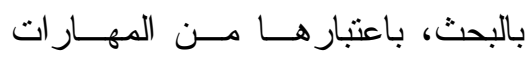
الأساسية للغة العربية التي يو اجه فيها التلاميذ صعوبات كبيرة، و إثــكاليات كثيرة.

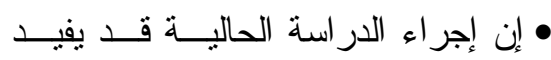

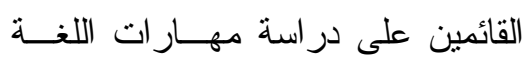
العربية، وتتميتها، و المـشكلات التـي دهي 
• الحــدود البـشرية: اقتــصرت هــذه

الدر اسة على تلاميذ الصف الـسادس

الابتدائي بمدينة نجران، البالغ عددهم

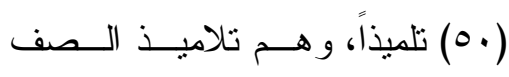

السادس الابتدائي بمدرسة عبد الله بن

$$
\text { مسعود الابتذائية. }
$$

• الحدود الزمانية و المكانية: اقتــصرت

هذه الدر اسة على عينة الدر اسة خلال

الفصل الدر اسي الثــاني مــن العـــام

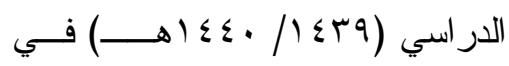

مدينة نجر ان.

\section{مصطلحات الدراسة: - مصاسة}

تضمنت هذه الدر اسة بعــض المــصطلحات

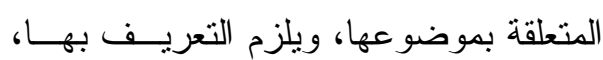

وهي:

فاعلية: تعرف بأنها "مدى الأثز الذي

يمكن أن تحدثه المعالجة التجريبية باعتبار ها متغير اً مستقلاً في المتغير ات التابعة"(شــــاته

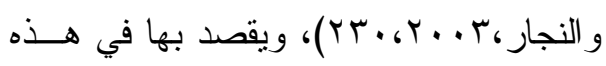

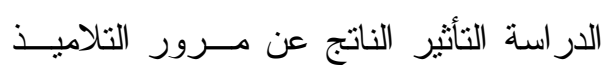
بخبرات البرنامج المقترح لعلاج الصعوبات الإملائية لدى تلاميذ الصف السادس، وبيــان

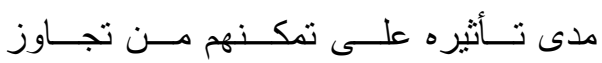
الصعوبات الإملائية المستهدف علاجها فـي ملي

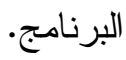

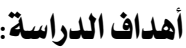

تسعى هذه الدر اسة إلى تحقيق الأهداف

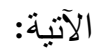

- التعرف إلى الصعوبات الإملاتئية الأكثر

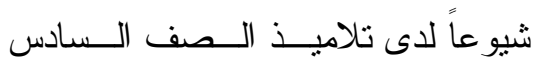

$$
\text { الابتدائي. }
$$

- بيان الأسس اللازمــــة لبنـــاء برنــامج

مقترح للتغلب على الصعوبات الإملائية الثائعة للديهم. ملنح

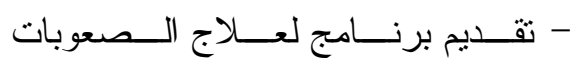
الإمالائية، لدى تلاميذ الصف الـسادس، ومعرفة فعاليته في تحسن مسستوياتهم التحصيلية في الإملاء.

- تقديم مقترحسـات وتوصــيات تـسـاعد مخططي مناهج اللغة العربيــة علــى تطـــــير البــــر امج و الإســـــر اتيجيات

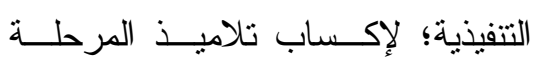
الابتدائية مهار ات اللغة العربية، ومنهــا

$$
\text { المهار ات الإملائية. }
$$

حدود الدراسة:

أجريت هذه الدر اســـة ضــــن الحــدود الآتبة:

• الحدود الموضوعية: اقتصرت هــذه

الدر اسة علــى المهـــار ات الإملائيـــة

الأساسية المقررة على تلامبذ المرحلة 
لاختبار هم كتابة صـــحيحة، وعــدم رســـها

بالشكل الصحيح الذي يتطابق مـــع القطعــة

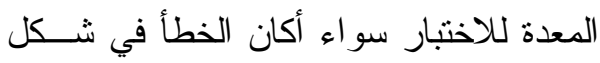

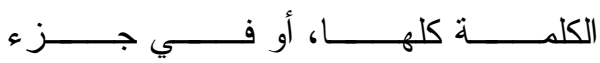

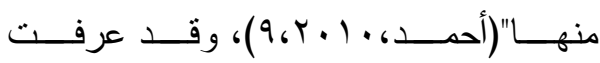

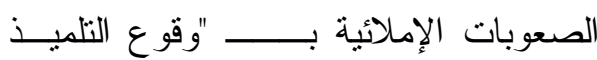
في أخطاء تتجاوز مو اطن الخطأ المتوقعـــة كالهزة بأثكالها المختلفة حسب موقع الكلمة و الهززة، و الألف بأثكالها، و التاء المربوطة

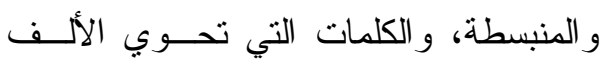
"ت

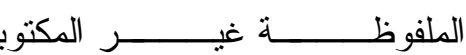

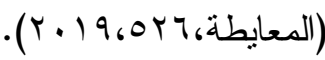

ويقصد بالصعوبات الإملائية في هذه

الدر اسة: الكلمات التي تخالف فـي رســمها القو اعد الإملائية التي اتفــق عليهـــا علمـــاء الإملاء، و التي درسها تلاميذ الصف السادس الابتدائي بصورة معينة، حسب ما وردث في الظاهرة الإملائية لمنهج (لغتــي الجميلــة) بالصفوف الر ابع و الخامس و الــسادس فـي المملكة العربية السعودية، فلا يـــخل فيهــا الكلمات التي تكتب في دول أخرى بــصورة مخالفة نتيجة لاختلاف العلماء فــي القاعــدة الإمالئية.

الإطار النظري والدراسات السابقة

سيتتاول الباحث في هذه الجزئية مسن

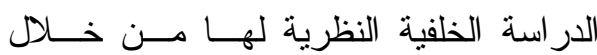
محورين هما: الإطار النظــري للار اســة،
برنـامج علاجي: يعـرف البرنــامج

العلاجي بأنه:"نظام، أو نسق متكامــل مــن

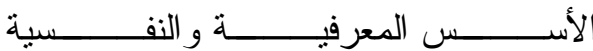

و الاجتماعية،وو العناصـــر المتكاملـــة معهــــا، كالأهداف، و المحتوى، وطر ائــق التــدريس و أساليبه، و التقويم، وما تقدمه مؤسسة ما إلى

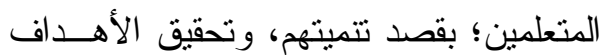

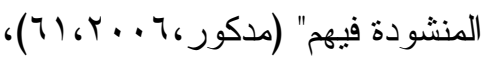
وعرف بأنه برنــامج يهــدف إلــى

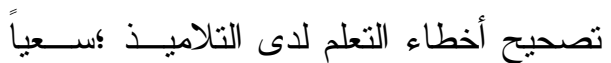
للوصول إلـى مسـستوى إتقــان الــدروس المستهدفة بعد إجر اء اختبــار ات تشخبــصبة قصيرة (الخليفة ومطاوع، 0 ا.ب). ويقصد بـه في هذه الار اســـة: نــسق، وتتابع من الإجراءات، و الممارسات التعليمية التي تحقق في النهاية خطة تعليميــة تـشـمل الأهداف، و المحتوى، و الإجر اءات التدريسية

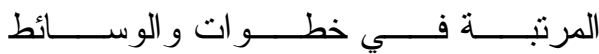
التعليمية،وو الأنـــشطة التعليميــــة و اللغويـــــة، و أساليب التقويم المناسبة؛ لمعالجة الصعوبات الإملائية التي يعاني منهــــا تلاميـــذ الــصف السادس الابتدائي.

الصعوبات الإملائية: "عبــارة عـن

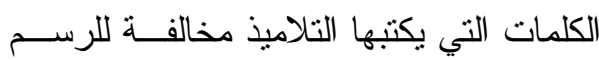
الصحيح في اللغة العربية عند إملائها عليهم"

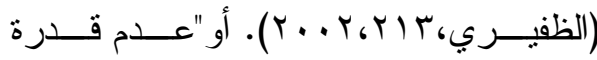

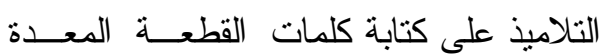


الملاحظة، وتعود النظافــة و التزتيــب

$$
\text { و الأناقة و غير ها. }
$$

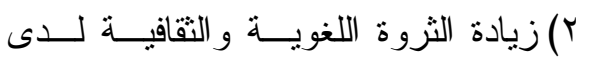

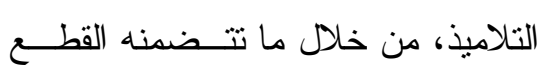

المملاة من معلومات جديدة، تضيف لهم هن شيئًا جديداً.

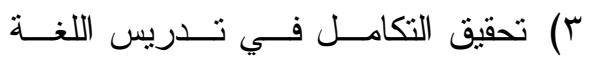
العربية، بحيث يخدم الإملاء فروع اللغة

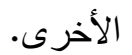

§) القدرة على كتابة المفردات اللغوية التي الآي

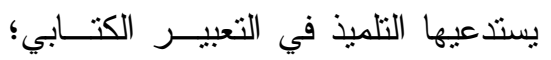
ليتاح له الاتصال بالآخرين من خــلال

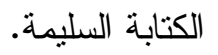

0) مساعدة التلامبذ على استخدام علامــات

$$
\text { الترقيم في كتاباتهم بصورة صحيحة. }
$$

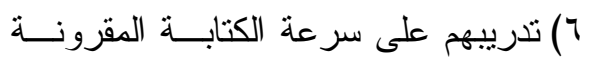

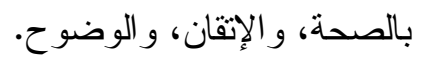

\section{م مفهوم الإملاء:}

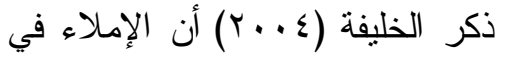

الماضي يقوم على أساس اختبار التلاميذ في

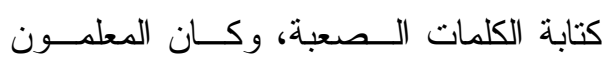
يتتافسون في ذلك فيرسب أغلب التنلاميذ، أما

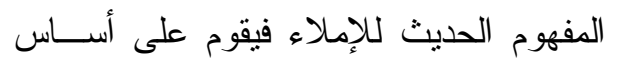

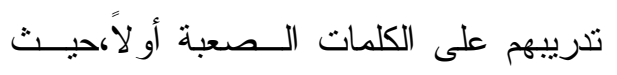
تعرض الكلمات الجديدة أو الــصعبة أمسـام

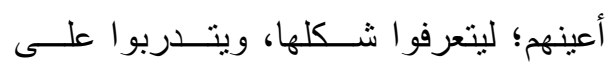
كتابتها، ويستمعو النطق صورتها من المعلم، لئحون،
و الدر اسات و البحوث الــسابقة ذات الــصلة بموضوع الدر اسة، وفيما يلي تفصيل ذلك: أولا: الإطار النظري: م أهمية الإملاء:

يعد الإملاء من الأسس المهمة للتعبير

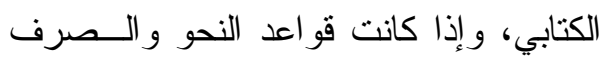
وسيلة لصحة الكتابة نحوياً واشــنقاقا، فـإن وان

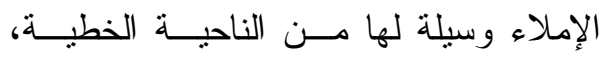

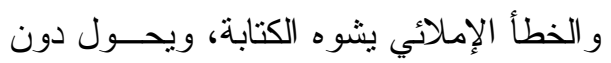

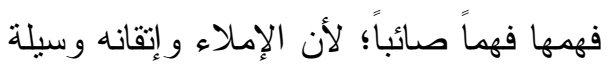

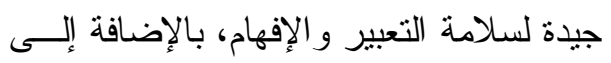

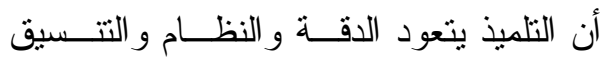
و الإجادة. (الربعي وصالح، ب ( ب ب). م أهد (ف تدريس الإملاء:

إن الهدف من تدريس الإملاء يجــب

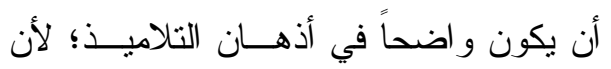

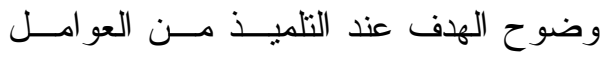
المهمة لإيجاد الدافع للتعلم، ولتنريس الإملاء

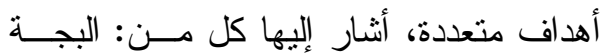

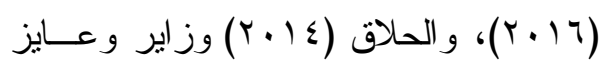

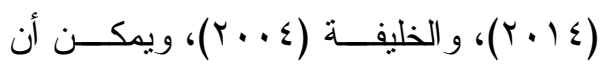

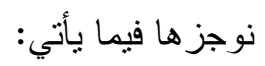

() اكتساب التلاميــذ عــادات و اتجاهـــات صحيحة عند الكتابة، كالإصغاء وحسن

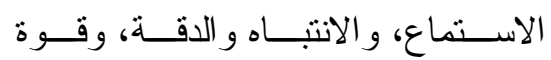


أمامهم؛ لينقلو ا أيّـــــة كلمـــة لا يـستطبيعون

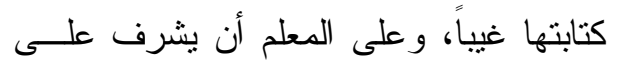
عملية النقل، ويناسب هذا النوع من الإمــلاء

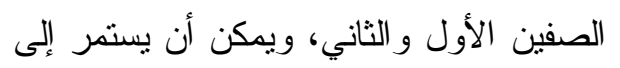
الصف الثالث الابتدائي. ثانياً: الإملاء المنظور : لا يختلف هذا النــوع عــن الإمــلاء المنقول، إلا بوجوب حجب النص الإملائسي

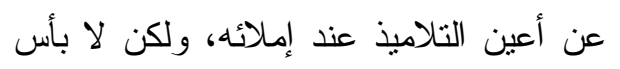

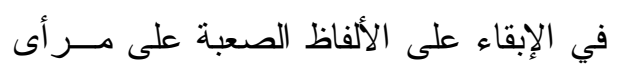

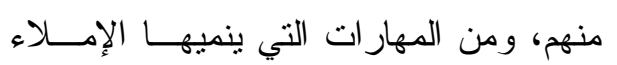
المنظور ملاحظة أنكال الكلمات و الحروف، وتمييز أوجه النتابه و الاختلاف بينها، وربط الرموز بدلالاتها المعروفة، وإعادة كتابتهـــا

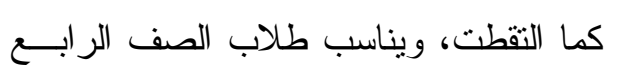
الابتدائي.

\section{ثالثاً: الإملاء الاستماعي:}

وهو الذي يفهم مدلوله مسـن خــله تسميته، إذ لا يُعرض فيه الــنص الإملائسي

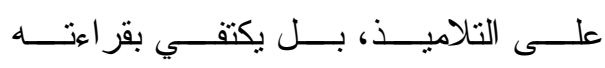

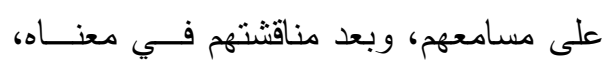

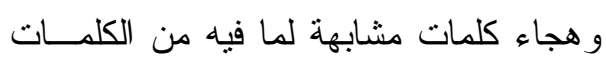

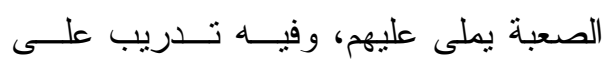

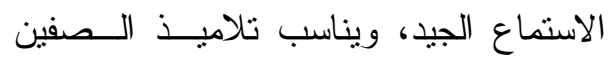

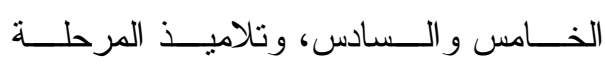
المنو سطة.
وينطقو ها كذللك، حتى ترسخ صـــور ها فـي

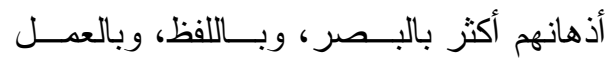

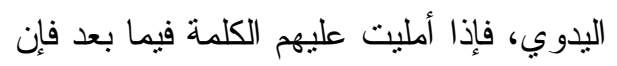

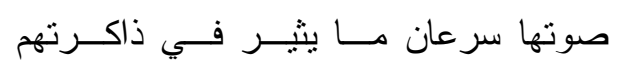

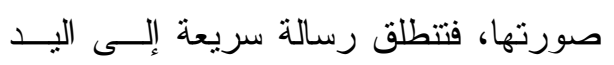
فتكتب الكلمة، وكلما كان التـذكر و واضـــــاً كانت استجابة اليد سريعة.

ويرى الباحــث أن عمليــة تــدريب

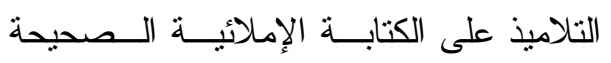

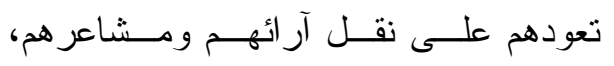
وحاجاتهم وما يُطلب إليهم نقله إلى الآخرين بطريقة صحيحة. م أنواع الإملاء وطرق تدريسها: يقسم التربويون الإملاء إلى عدة أنواع

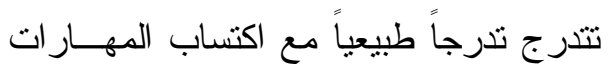

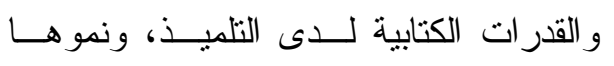
وتدرجها في صفوف كل مرحلة، وقد أجمع

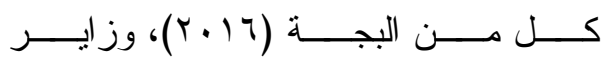

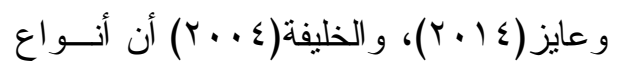
الإملاء أربعة: أولاً: الإملاء المنسوخ (المنقول): وير اد به نسخ القطعة الإملائية مـن الرمن

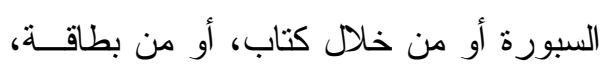
وبعد قر اعته ومناقتته مع التلاميذ يقوم المعلم

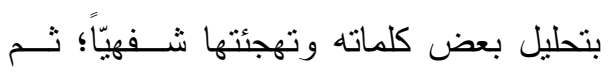
يُمليه عليهم على أن ييقى النص معروضــــاً 
ويكتبها كتابة سليمة، ممــا يسـهل مرحلــة

التحليل عبر أسئلة موجهة تهدف إلى استتناج وهو الذي يستهذف قيــاس قــدرات

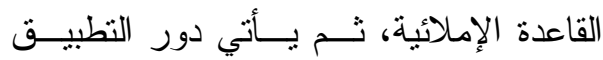
التلاميذ، ومدى تقدمهم في الكتابة الإملائيــة

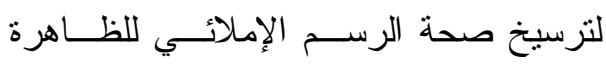

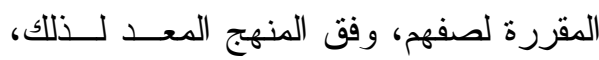
المستهدفة (وز ارة التربية و التعليم، ب ا • ץ). م أنواع الصعوبات الإملاية:

أصبحت ظاهرة الصعوبات الإملائية

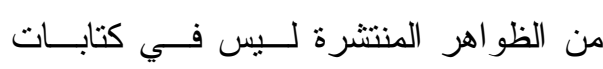
ولهذا لا تعرض- أمام التلاميذ- أية كلمة من

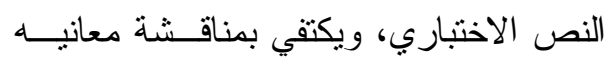
العامــة، إذا كان الأمر بيتدعي ذلك، أما إذاري كان قد سبق وأعطي لهم هذا النص درساً في التلاميذ في مر احل التعليم العام المختلفة، بل القر اعة الاستيعابية فلا داعي لهذه الخطــــوة. تعدتها إلى كتابات طلاب الجامعة. وقد أثنار

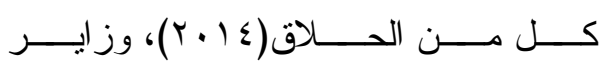
و هذا النوع يصلح لتلاميذ الصفين الخــامس لـاهي و السادس، وتلاميذ المرحلة المتوسطة.

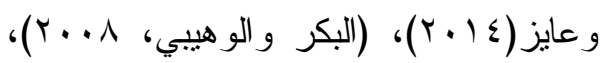
ويؤكد الباحث أنه في جميع الأحوال،

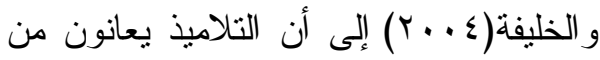
بعض الصعوبات الإملائية، وتكثر أخطاؤهم

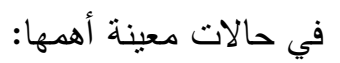
- التنوين بأنو اعــهـ نـــباً، وجـــراً، ورفعاً. - تاء التأنيث بنوعيها، و هاء الغائب.

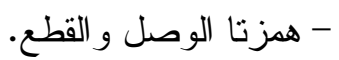
- الهمزة في وسط الكلمة بأنو اعها. - الهمزة في آخر الكلمة بأنواعها. - التاء المربوطة و التاء المفتوحة. - اللام الثمسية و اللام القمرية. - زيادة بعض الأحرف في الكلمة. - حذف بعض الأحرف من الكلمة. - الألف المتطرفة بنو عيها.

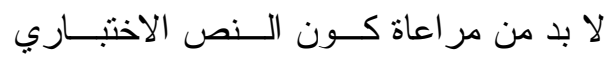
يناسب مستوى تلاميذ الصف سواء أخذ من كتاب القر اعة أو من أي مصدر آخر . م منهجية تقديم درس الظاهرة الإملائيــة في المرحلة الابتدائية وفق منهج لغتي لفي لهني الجميلة: في المرله

اعتمد في تدريس الظاهرة الإملائيــة بالمرحلة الابتدائية على الطريقة الاســتقر ائية التي تبدأ بملاحظة كلمات الظاهرة المستهدفة في جمل منتزعة من نص الفهــم القرائـي،

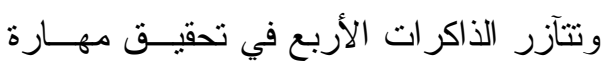
الملاحظة حيث يرى الطالب كلمات الظاهرة

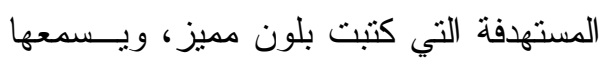

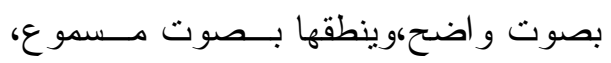




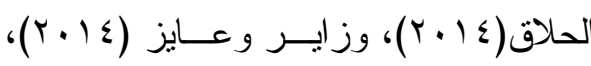

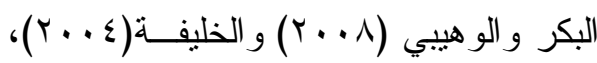

$$
\begin{aligned}
& \text { و أجملو ها فيما يلي: } \\
& \text { - أسباب ترجع إلى المعلم: وتتمثل في: }
\end{aligned}
$$

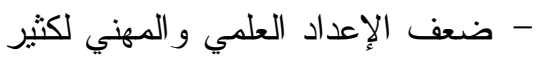

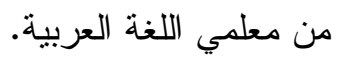

$$
\begin{aligned}
& \text { - عدم اهتمام معلمي المــو اد الدر اســـية } \\
& \text { الأخرى بأخطاء الطلاب الإملائية. } \\
& \text { • أسباب ترجع إلى الطالب: وتتمثل في: }
\end{aligned}
$$

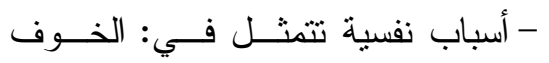

$$
\begin{aligned}
& \text { و التزدد، وعدم الثقة، وعدم الاستقرار } \\
& \text { الانفعالي. }
\end{aligned}
$$

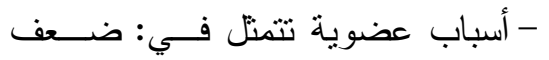

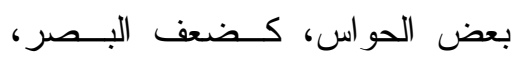

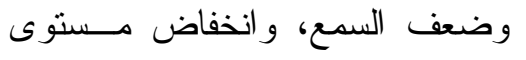

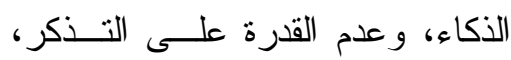

$$
\text { و عيوب النطق. }
$$

- أسباب ترجع إلى طبيعة الكتابة العربية:

وتتمثل في تشعب قو اعــــ الإمــلاء،

واختلاف صورة الحرف باختلاف موضــعه

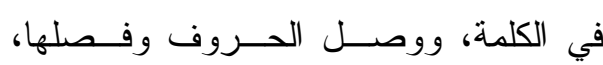

وتشابه الكثير من الحروف العربية من حيث وروفي وفي

الرسم و الثكل، أب وضع الحركات على كل

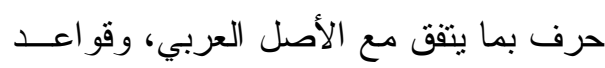

اللغة.
- الخلط بين الحروف المتشابهة رسماً

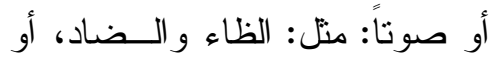

بعض الكلمات التي يخطــــ فئ فيــا

التلاميذ بسبب نشابه المخرج مثنـل:

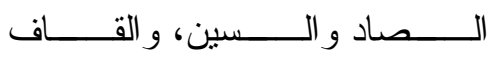

$$
\text { و الغين.....إخ. }
$$

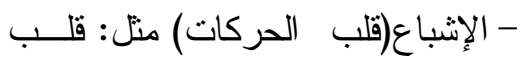

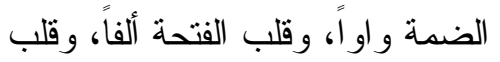

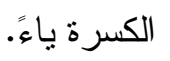

- الكلمات المبدوءة بـ بـ (أل) التعريف

$$
\text { إذا سبتقها (الباء، الكاف، الفاء). }
$$

- دخول (أل) التعريف على الكلمــات

$$
\text { التي تبدأ بحرف اللام. }
$$

م أسباب الصعوبات الإملائية:

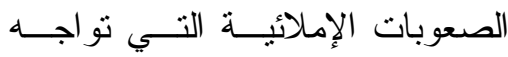

التلاميذ في تعلم القراءة والكتابة هـي مسـن

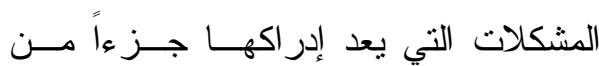

المهار ات الأساسية التي ينبغي أن ينتاولها أي إي

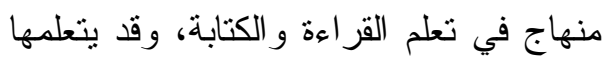
التناميذ بالمحاكاة و الممارسة من غير لثئ إثارة

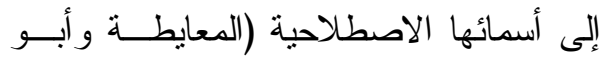

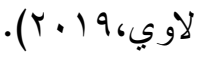

وقد أجريت الكثير مــن الدراســات

لمعرفة أسباب الصعوبات الإملائية، وبـــرغم كثرة هذه الأسباب إلا أنها منتشابكة ومتداخلة،

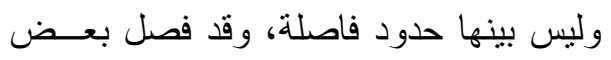

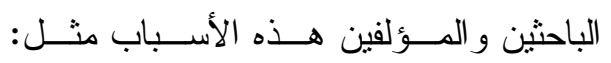


ثانياً: أن يصحح المعلم دفاتر التناميــذ

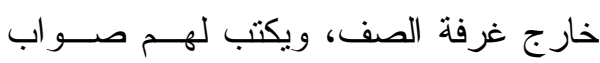
أخطائهم على أن يكلفهم بتصحيحها فيما بعد، وله وله ويؤخذ على هذه الطريقة أن الفاصل الزمني لني

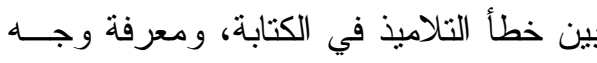

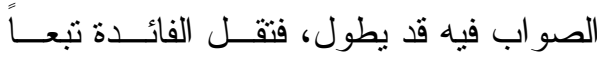
لذلك.

ثالثاً: أن يعرض المعلم علــى التلاميــــ

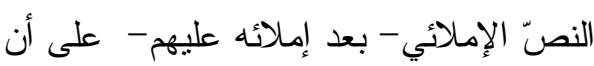
يصحح كل تلميذ أخطاءه بالرجوع إليه، و هذه

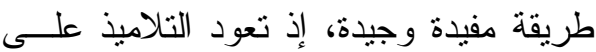
دقة الملاحظة، و التقـــة بــالنفس و الاعتمــاد عليها، كما تعودهم الصدق و الأمانة، وتقدير المسؤولية، و الثجاعة على الاعتر اف بالخطأ

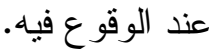

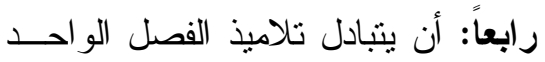

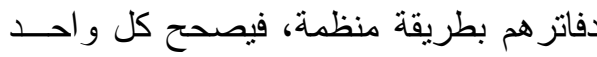

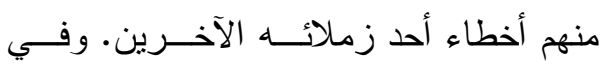

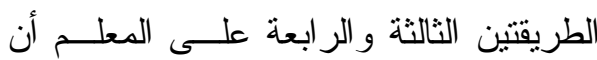
يجمع بينهما، وبين أسلوب التصحيح بنفسه، وذللك بالإثــر اف المباثتـر علــى عمليــة التصحيح، ثم بالاطلاع على عدد محدود من بن

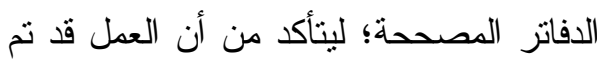

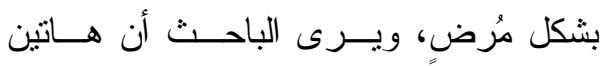

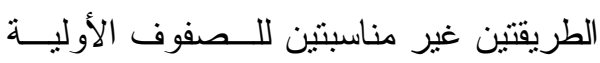
من المرحلة الابتدائية.
- أسباب تريويــة ترجــع إلـــى طريقــة التدريس المستخدمة: وتتمنل في أن بعض المعلمين يدرس

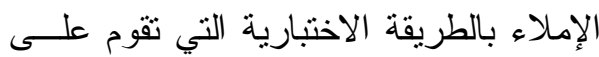

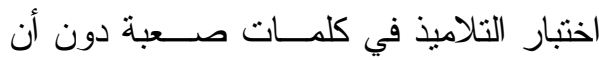
يدربهر على ملاحظة الرمــوز المقــروءة، و المكتوبة في دقة، إضافة إلى قلة التمــرين على الربط بين الرموز ودلالاتها، و التهــاون في تتمية القدرة على الاستماع الدقيق؛ لتمييز

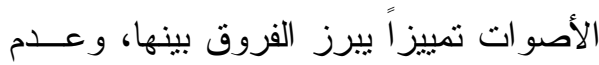

$$
\begin{aligned}
& \text { التدريب الكافي على القو اعد الإملائية. } \\
& \text { م طرق تصحيح الإملاء: }
\end{aligned}
$$

هنالك طرق متتوعة لتصحيح القطع

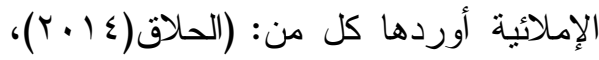

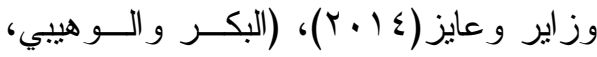

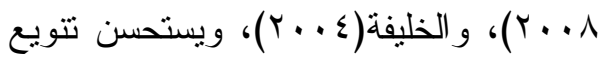
الأساليب حسبما تقتضيه الحاجة، وأثنهر هذه ولهن الطرق ما يلي: أولاً: أن بصحح المعلم دفتر كل ثلميذ

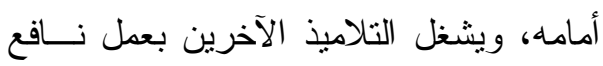

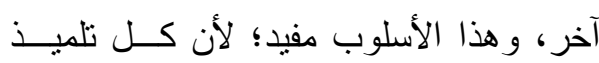

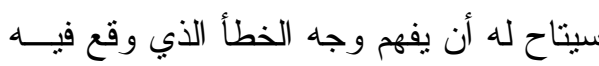

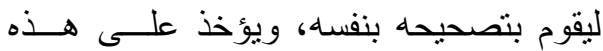
الطريقة أن بقية التلاميذ قد بنصرفون عـن بئن العمل الجاد إلى اللعب و العبث. 


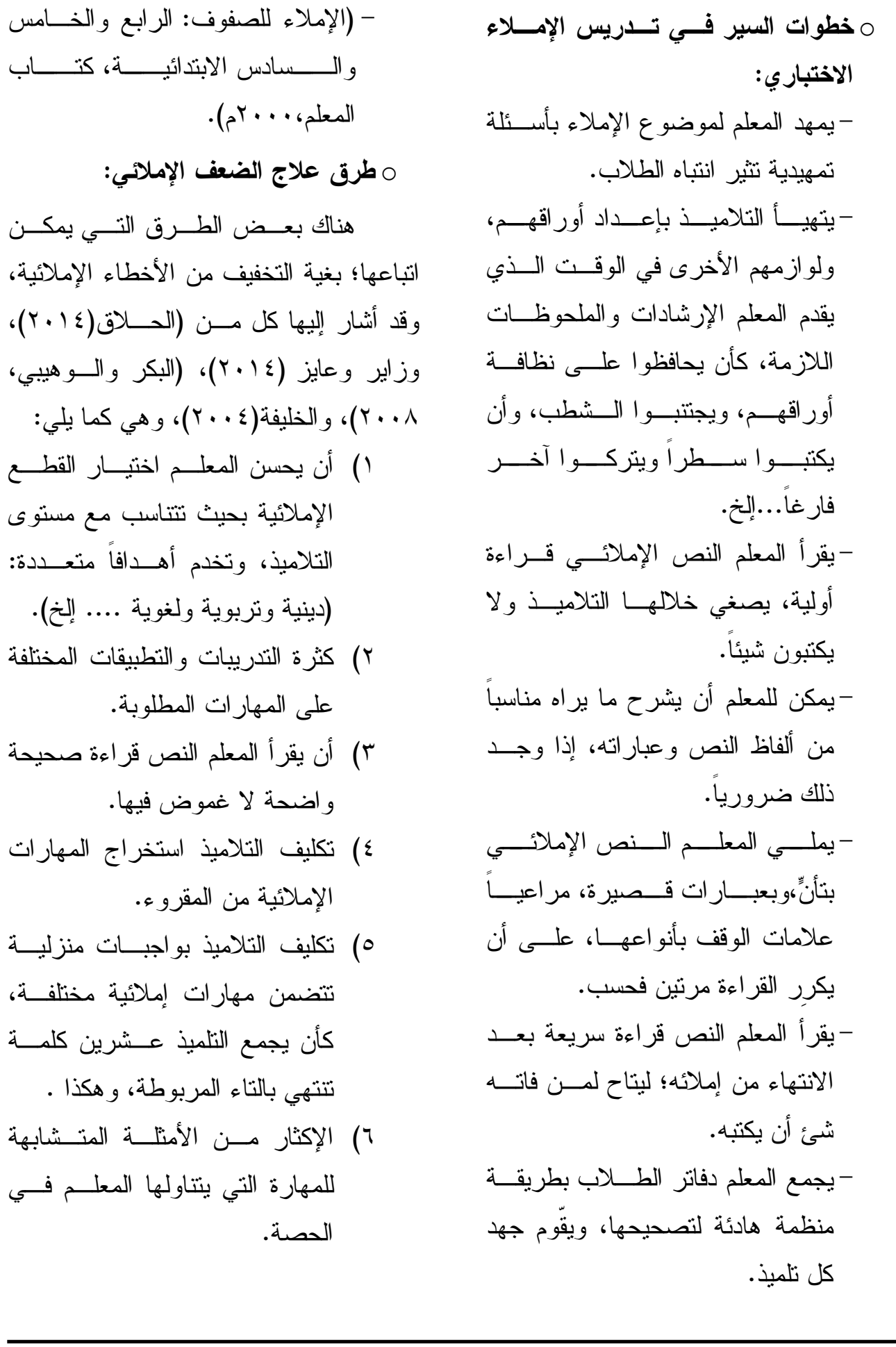


1 (1) نتويع طرق تدريس الإملاء؛ لطرد

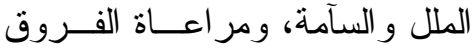

الفردية بين التناميذ.

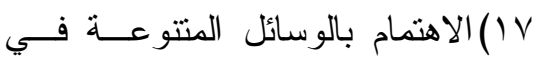

تدريس الإملاء، و لا سيما السبورة بلوسئل

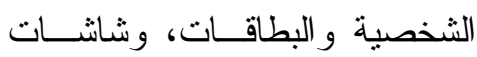

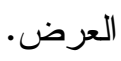

1 (1)تشجيع التلاميذ الــذين تحسـنو ا،

وتحفيز هم بمختلف أساليب التحفيز

و التشجيع. ونهير

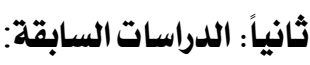

نظر اً لما تمثلكه الدر اسات السابقة مــن

ر رافد قوي يسهم في إثراء الدراسة الحاليــة،

فسيعرض الباحث أهم الدر اسات، و البحـــوث

ذات الصلة بموضوع در استه الحالية التـي

تمكن من الاطلاع عليها، وقد اتبــع منهجــاً

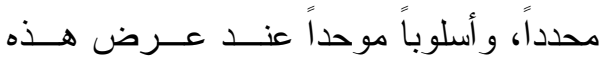

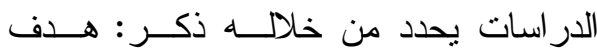

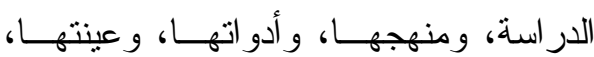

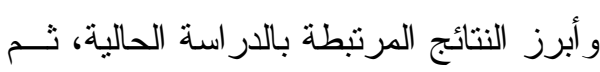

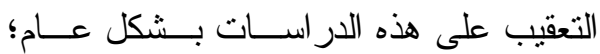

بهذف الاستفادة منها، وإظهار أوجه الاتفاق، لهان

و الاختلاف معها، وقد رأى الباحث ترتيـبـب

هذه الدر اسات، و البحوث ترتيباً تأريخياً مسنـ

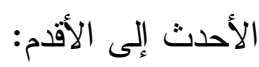

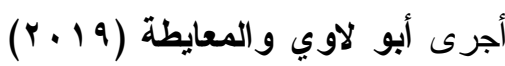

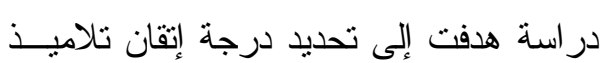

( الاهتمام باســتخدام الـسبورة فــي الكلمات الصعبة فيها.

^) تدريب الأذن على حسن الإصـــاء لــاء لمخارج الحروف.

9) جمع الكلمات الصعبة التي يـشكو

منها كثير من التلاميذ وكتابتها، ثم لثمات

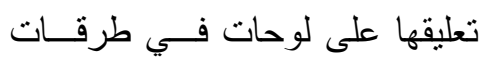

$$
\text { المدرسة وساحاتها. }
$$

• (1)تخصيص دفاتر لضعاف التلاميـذ

تكون في معيتهم كل حصة.

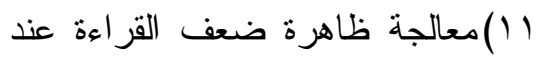

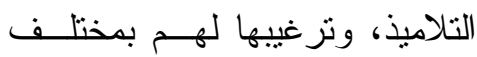

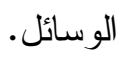

r (1) عدم التهاون في عملية التصحيح.

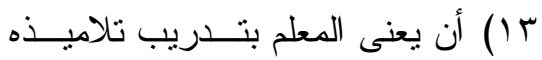
على أصوات الحروف، ولا ســيما

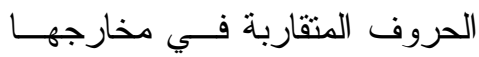
الصوتية، وفي رسمها.

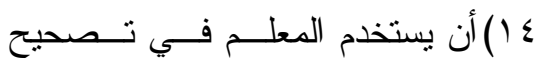

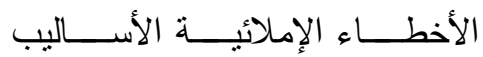

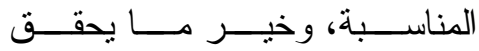
ذلك مساعدة التلميذ على كـشف خطئه بنفسه، وتعـرف الــصواب بجهذه.

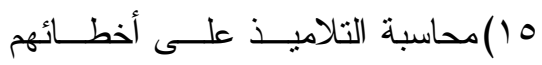
الإملائية في المو اد الأخرى. 


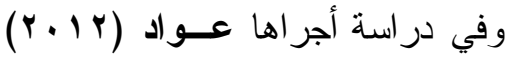

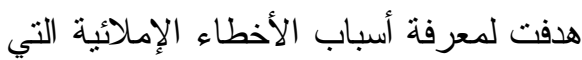

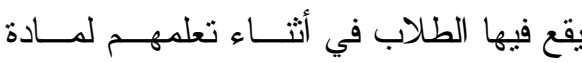

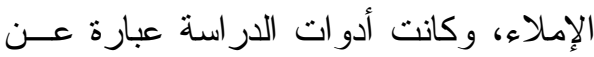

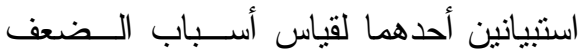
الإملائي عند طلاب الصف الثاني المتوسط، والآخر لمعرفة أسلوب التدريس، وأما الأداة

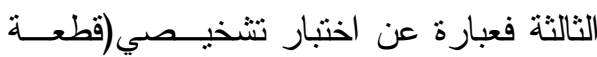

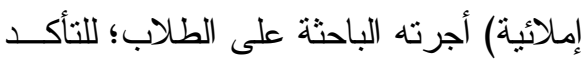
من وجــود المــشكلة وتحديــدها، وتحقيـق أهد افها، وطبقت أداة الدر اسة على عينة مسنـ طلاب الصف الثاني المتوسط ضن منطقـــة السيدية التابعة لمديرية تربية بغــداد،وتكونت

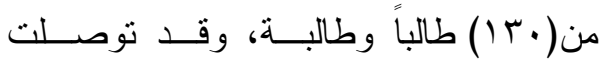

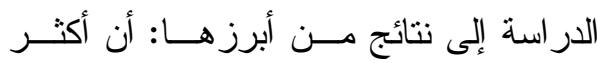

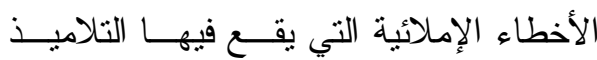

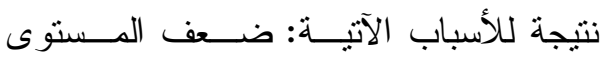
التحصيلي في القر اءة بأنو اعها،و إسناد تعلــيم

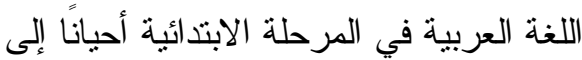
معلمين غير متخصصين، أو ذوي مستويات متدنية، إضـافة إلى عدم الاهتمام مــن قبـــلـ

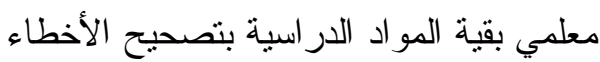
الإملائية التي يقع فيها التلاميذ.

ومن جهنهما قام عاثور و الحوامــدة

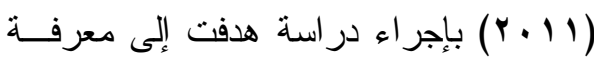

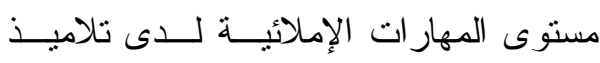
الصف السادس الحافظين وغيــر الحــافظين
الصف السادس الأساسي للمهار ات الإملائية

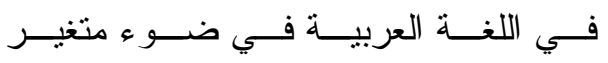
الجنس،وتكونت عينة الدر اسة من(هوه تلميذاً وتلميذة، ولتحقيق أهداف الدراسة اعنمـدت

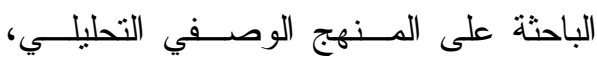

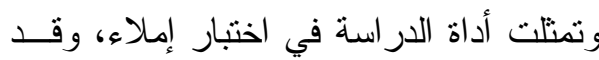
توصلت الدراسة إلى عدد من التوصيات من أبرز ها: توظيف طر ائق حديثــة وأســاليب

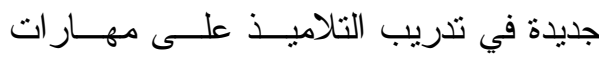

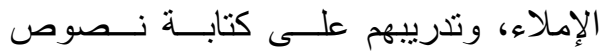

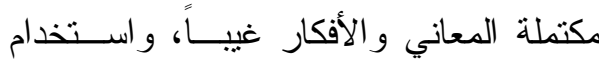

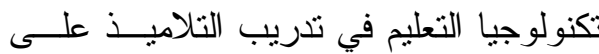
مهار ات الإملاء. كما أجرت الهدباني (1 1 • r) در اسة هدفت إلى معرفة فاعلية برنامج تعليمي قائم على إستر اتيجية الحواس المتعـددة لعسلاج بعض صعوبات الإملاء لدى التلميذات ذوات صعوبات التعلم، وكانت أداة الدراسة عبــارة

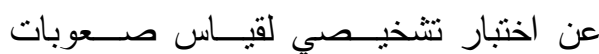

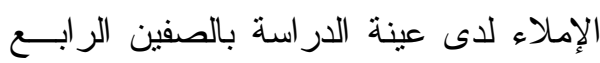
و الخامس الابتدائي، وتكونت عينة الدراســة من(·) تلميذة، وقد توصلت الدر اسة إلـى ونى

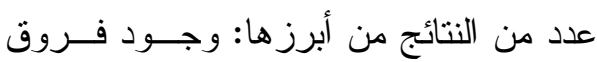
ذات دلالة إحصائية عند مسستوى الم، ابــين رتب درجات التلميذات في القيــاس القبالــي و القياس البعدي بعد تطبيق البرنامج لــصالح

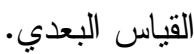


تدريبية؛ لتبصير هم بفكرة البرنامج، ونزويدهم

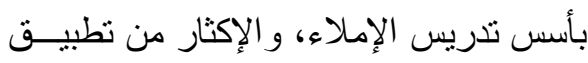

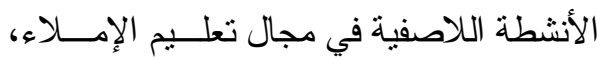

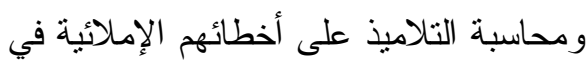

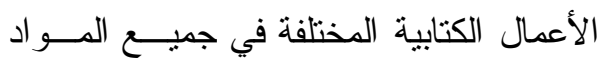

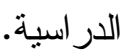

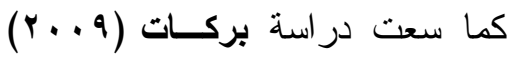

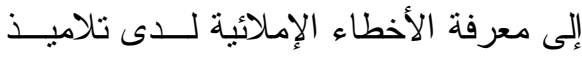

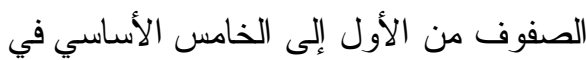

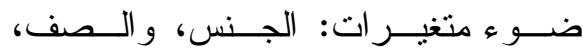
و التحصيل. ولتحقيق أهداف الدراسة صـمم الباحث أداة للار اسة تتكــون مــن خمـسـة نصوص إملائية تتاسب التلاميذ من الــصف الأول إلى الصف الخامس الأساسي، وطبقهــا

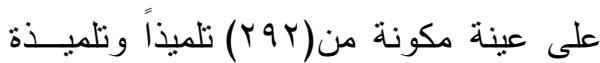
بمدينة طولكرم بفلسطين، وقد أظهرت هـــه

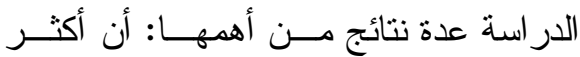

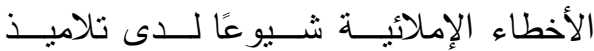
الصفوف من الأول إلى الخامس الأساسي هي لتهي

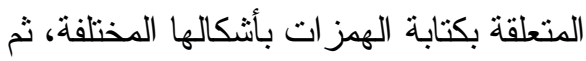
الخلط بين التاء المفتوحة و التاء المربوطـــة، بينما كانت الأخطاء الإملائية الأقل شـيــاهـا هي قلب الحروف، و إسقاط سن الحروف(س، الإسله وص، وش، وض)

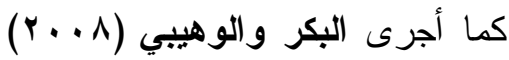

در اسة هدفت إلى تعرف الأخطاء الإملائيــة الثائعة لدى تلميذات الصف الثالث المتوسط

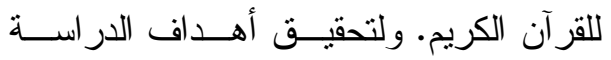
استخدم الباحثان المنهج البنائي، ومنهج حلقة البحث، و المنهج الوصفي، وقد اختار ا عينــة عشو ائية بسيطة مـنـ التلاميــــ الملتحقـين بمراكز تحفيظ القرآن الكريم بمحافظة إربد، بـان

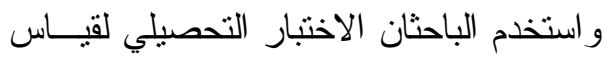

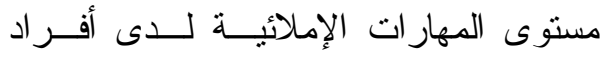
الدر اسة، وقد توصلت الدر اسة إلى عدد مــن

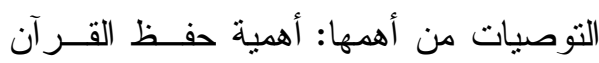
الكريم وتلاوته في تتمية المهارات الإملائية، و العمل على زيـــادة النــصوص الإملائيــة المقررة في كتب اللغة العربية، وربط الكتاب المقرر بعلوم القرآن الكريم.

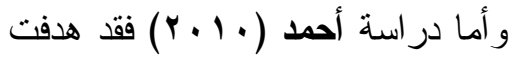

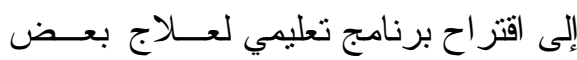
الأخطاء الإملائية العربية الثائعة في كتابات تلاميذ الصف الخامس الأساسي، و إلى معرفة

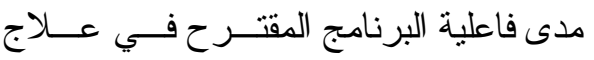
الأخطاء الإملائية العربية الثائعة، وموازنته بالمنهاج المدرسي الذي يدرس الذي يــدرس بالطريقة العادية، وكانت أداتا الدر اسة عبارة عن بناء برنامج تعليمي، و الثانية بناء اختبار للمهار ات الإملائية؛ لقياس تمكن الطلبة مــن لـن هذه المهار ات، وقد تكونت عينــة الدر اســـة

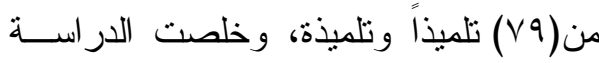
إلى عدد من التوصيات من أهمها: العنايــة

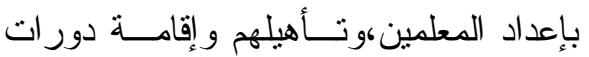


وقد توصلت الدراسة إلى عدد من النتائج من

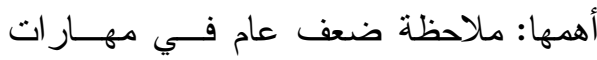

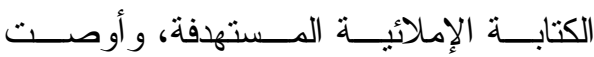
بضرورة معالجة الصعوبات الإملائية عـنـ

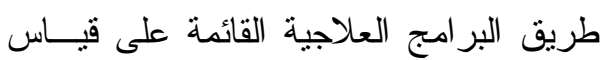
الأداء الإملائي لدى المتعلمين.

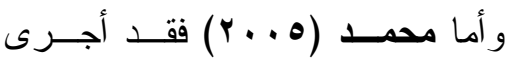

دراسة هدفت إلى تعرف أنمــاط الأخطــاء

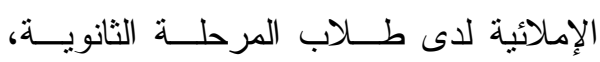

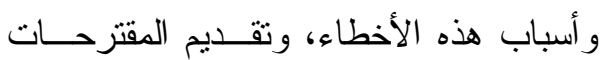
و الحلول لمعالجة هذه المشكلات الإملائية. ولتحقيق أهداف الدر اســـة اســتخدم الباحث المنهج الوصفي التحليلي، و المـنهج التاريخي، و أما أدو ات الدر اسة فقد تمنلت في

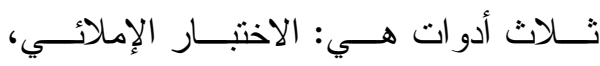
و الزيارات الميدانية لمدارس عينة البحــث، البه، وكر اسات الطلاب، وتوصلت الدراسة لعـدة نتائج من أهمها: أنه يجب على معلى وتي اللغة

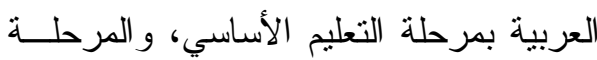
الثانوية يجب عليهم حصر الأخطاء الإملائية

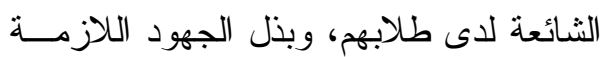

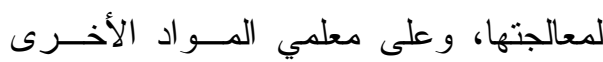
التعاون معهم في سبيل ذلك.

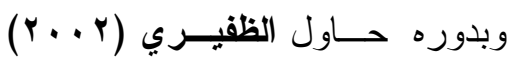
إجر اء دراسة تهدف إلى تعــرف الأخطــاء الإملائية الثنائعة في اللغة العربية عند تلاميذ

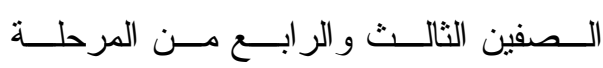

في مدينة الرياض، و استخدم الباحثان المنهج

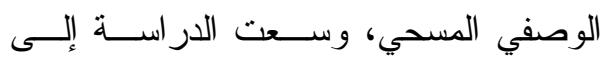

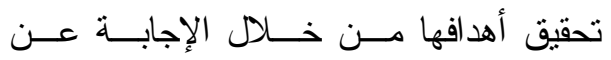
تساؤلاتها، وتكونت عينة الدراسة من (Y)

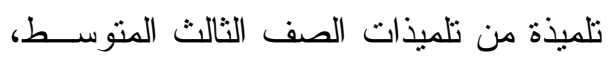

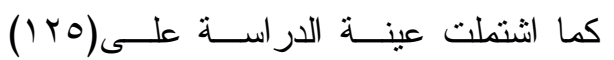
معلمة، و (rا7) مشرفة، وقد أسفرت الدر اسة عن عدد من النتائج من أهمها: الوصول وله إلى قائمة بالأخطاء الإملائية الثائعة عند تلميذات الثالث المتوسط بلغت (.0) خطــأ إملائيــاً شائعاً، و أكثر الأخطاء الإملائية شيوعاً جـاء لـاء

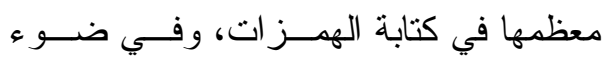

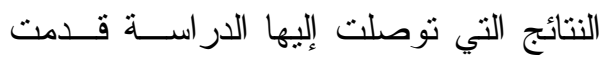
بعض التوصيات و المقترحات، ومن أهمهـــا:

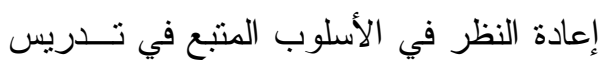

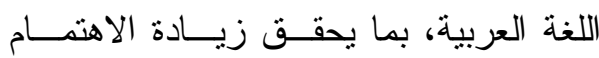

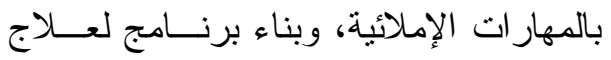

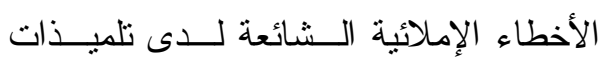
الصف الثالث المتوسط. من جانبه أجسرى حسن (r..V.

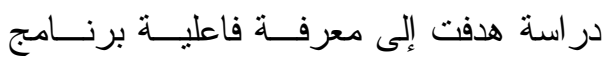
مقترح في علاج بعض الصعوبات الإملائية لاى الدارسين في الصف الثـاني الإعـــدادي

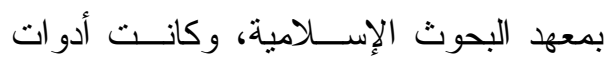

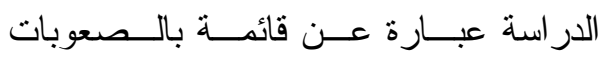
الإملائية، واختبار تشخيصي فــي الإمــلاء، وبرنامج التغلب على الصعوبات الإملائيـــة، 
المنطوقة ، و الهمزة المتوســـة، و الهمــزة

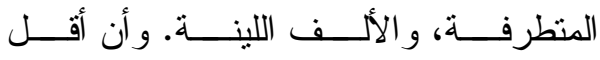

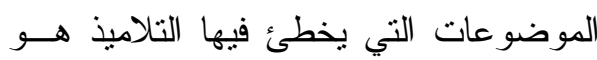
موضوع التضعيف.

م تعليق عام على الاراسات السابقة:

من خــالمل العــرض آنــــ الـــكر

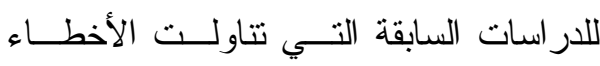

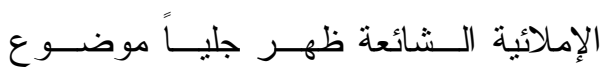

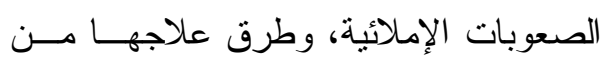

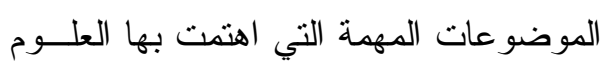

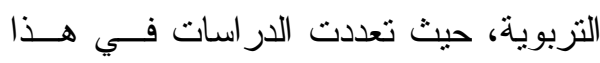
المجال، فأمدت الباحثين برؤية و اضحة عـنـن

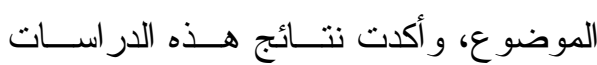

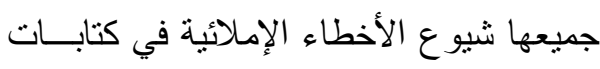
التلاميذ على اختلاف مستوياتهم التعليمية. م أوجه الاتفاق والاختلاف بين الاراســة الحالية و الدراسة الدراسات السابقة: اتفقت الدراسة الحالية مع الدراسات

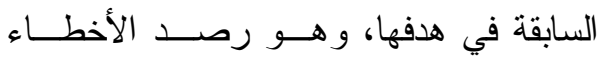

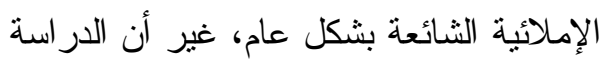

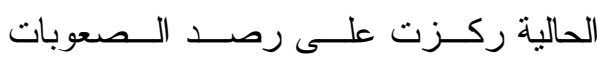

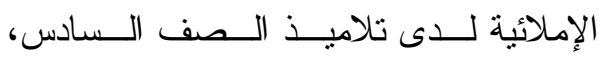
ومعالجتها بطريقة علميــة إجر ائيــة متبعــــة

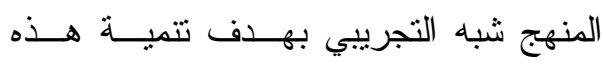
المهار ات، وقياس فاعلية البرنامج العلاجـي لئي المقترح، و الدر اسات السابقة اتبعت المــنهج الئج
المتوسطة بدولة الكويت. ولتحقيـق أهـــاف

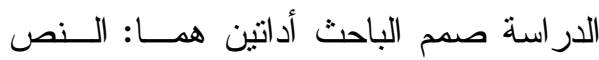
الإملانَـي، و اســنبانة تــشخيص الأخطــــاء

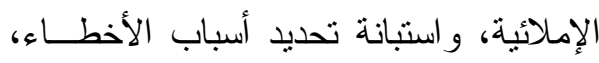

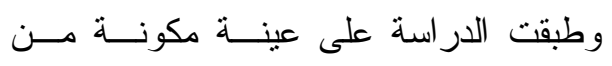
( اللغة العربية ومعلماتها، بالإضافة إلى (Yr)

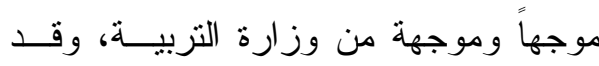

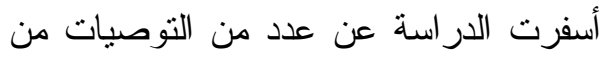
أهمها: إعادة النظر في الأساليب المتبعة في تدريس اللغة العربية بما يحقق زيادة الاهتمام

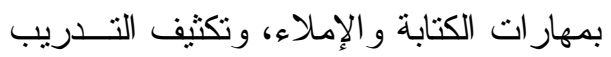
على المهار ات الإملائية في البيت و المدرسة، ولإنهاء وتتجيع التلاميذ على القراءة الحرة.

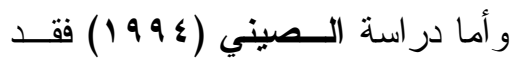

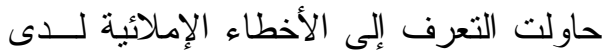

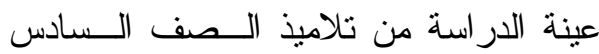

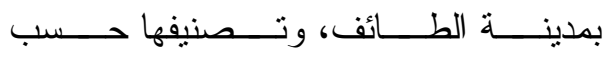

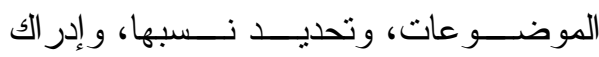
العلاقات التي يمكن أن تتشأ عن موضو عات

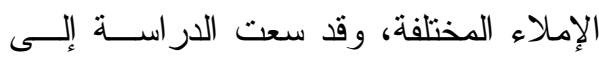

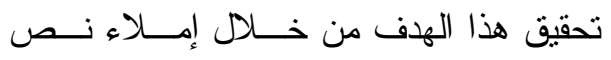

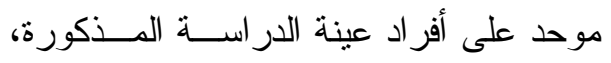
وتلخصت نتائج الدر اسة في الآتي : أن أكتـــر الموضوعات التي يخطئ فيها التلاميذ زيادة

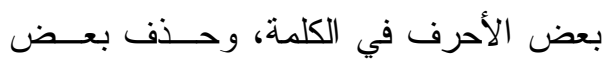

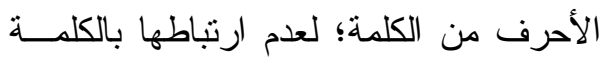


إضافة إلى در اسة الصيني( 99 (1)، و هذا ما يتفق مع نتائج الدر اسة الحالية. وقد أفادت الدراســـة الحاليــة مــن الدراسات السابقة في نطوير أدوات الدر اسة، وكيفية بنائها مثل :قائمة الصعوبات الإملائية، و الاختبار التحصيلي في الإملاء، و البرنــامج المقتر ح لعلاج الصعوبات الإملائية.

منهج الدراسة وإجراياتها

تتاولت الباحث فـي هــــه الجزئيــة الارسة الخطوات الإجر ائية للإجابــة عـنـ أسئلتها؛ من حيث تحديد مــنهزج الدراســة،

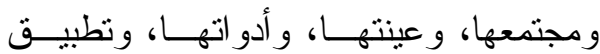
برنامجها.وفيما يلي تقصيل لذلك:

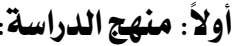

اعتمدت الدر اسة الحالية على المــنهج

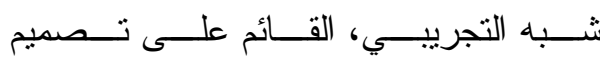

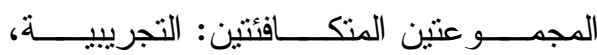
و الضابطة؛ وذللك لملاعهته طبيعة الدراســـة

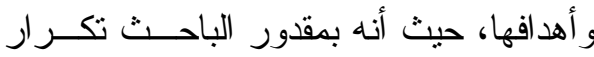
التجربة أكثر من مرة؛ للتأكد من صحة نتائج

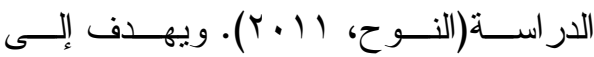
التعرف على فاعلية برنامج مقتـر ح لعــلاج

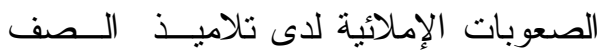

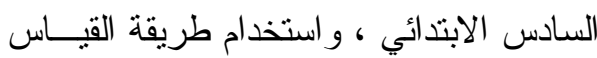
القبلي و البعدي.
الوصفي التحليلي في أغلبها سوى دراسـتي

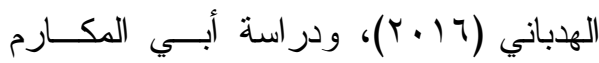

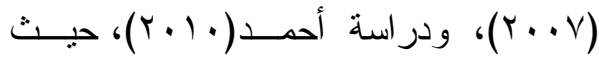
اتبعت المنهج شبه التجريبي، وهذا ما يتفـق ونق مع منهج الدر اسة الحالية.

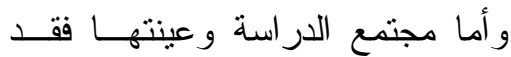

استخذمت بعض الدر اسـات مجتمــع و عينــة الدر اسة من طلاب المدارس الثانوية، كما في

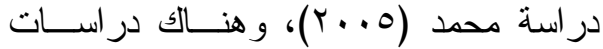
كانت عينة الدر اسة فيها مكونة من تلاميــذ

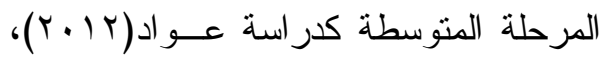

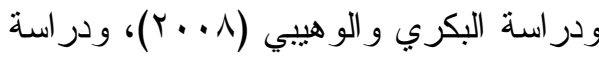

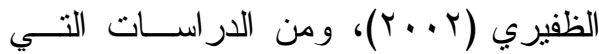
كانت عينة الدر اسة فيها من تلاميذ المرحلـــة الابتدائية در اسة عاشور و الحو امدة (1) بـ)،

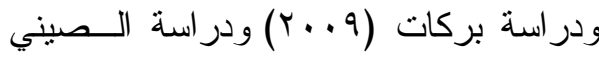
( 99 (1)، و هو ما يتفق مع الدراسة الحالية.

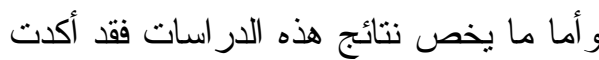
أغلبها أن أكثر الأخطاء الإملائية شيوعًا لدى لإه

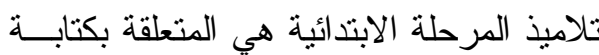

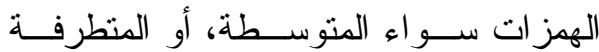
بأثكالها المختلفة، ثم الخلط بين التاء المفتوحة و التاء المربوطة، وزيادة بعض الأحرف في الكلمة، وحذف بعض الأحرف من الكلمــة،

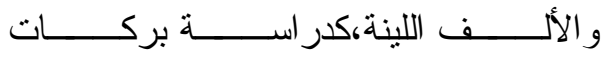

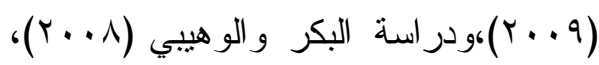


م أولاً: بناء قائمة بالصعوبات الإملاهيــة

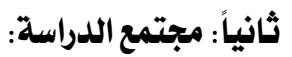

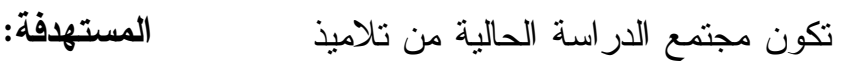

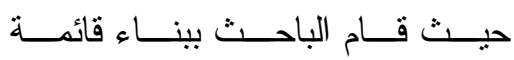

بالصعوبات الإملائية التي يعاني منها تلاميذ

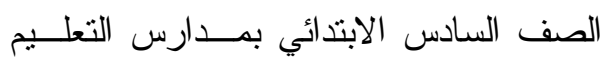

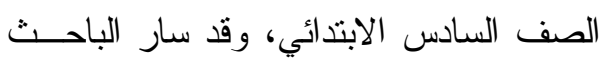

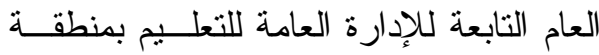

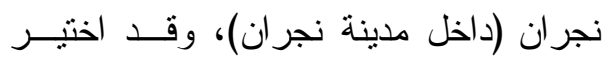

في بناء القائمة وفق الخطو ات الآتية:

الصف الساد؛ لأن تلاميذ هذا الصف قـــ

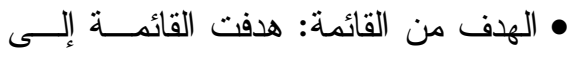

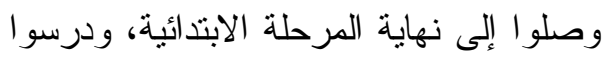

تحديد الصعوبات الإملائية الني يعساني هن هني

جميع مفردات الظاهرة الإملائية المقررة في لابنه

منها تلاميذ الصف السادس الابتــدائي؛

هذه المرحلة.

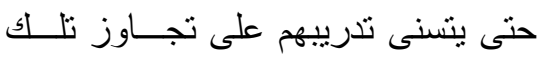

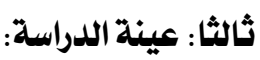

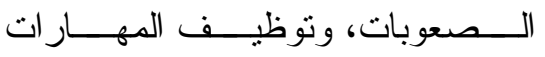

الإملائية الصحيحة في كتاباتهم.

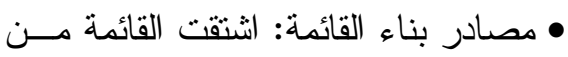

المصادر الآتية:(بعض الأدبيــات التـي لئي

عنيت بالصعوبات الإملائية، و الدر اسات التيات

السابقة في الموضوع نفسه. )

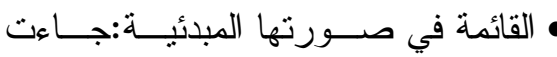

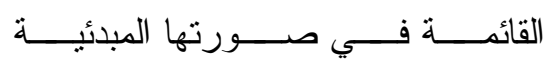

متضمنة(r ( ) صعوبة إملائية، ووضعت صنت

في صورة استبانة؛ ليسهل عرضها على إلى

السادة المحكمين.

• ضبط القائمة: وجهت الاسـتبانة إلـى لـى

وقع اختيار عينة الدراسة على تلاميـذذ

الصف السادس الابتدائي بمدرسة عبد الله بن

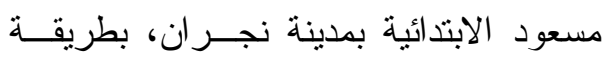

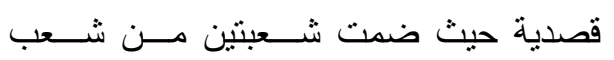

الصف السادس الابتــدائي، وعــددهم (•) تلميذاً، قسمو ا إلى مجمو عتين إحداهما تمثنل ولـل

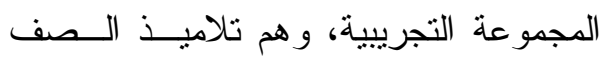
السادس الابتدائي (أ) و عددهم(Yo) تلميــذاً،

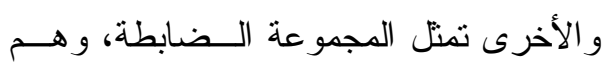
تلاميذ الـصف الــسادس الابتــدائي (ب)،

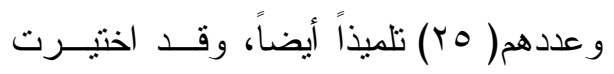
العينة بطريقة عشو ائية. مجموعـــة مــن الــسادة المحكمــين رابعاً: أدوات الدراسة:

المتخصــصين فـي تخــصص اللغـــة العربية، وفي المناهج وطرق التنريس، تمثلت أدوات الدراسة الحاليــة فــي

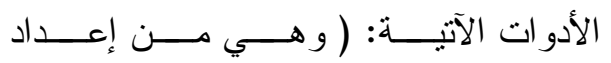
وبعض معلمي (لغتي الجميلة) بالمرحلة الباحث)

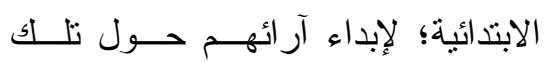


وضع الكلمات، ويعبر عن هذا النص في هذه

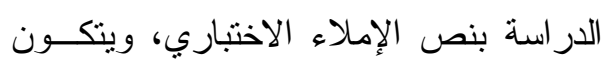

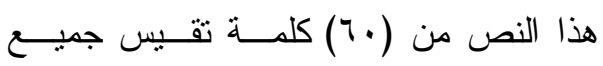
موضوعات الظاهرة الإملائية التـي وردت من لهن ضمن مفردات مقرر ات (لغتي الجميلة) مــن الصف الرابع إلى الــصف الـسادس مسن

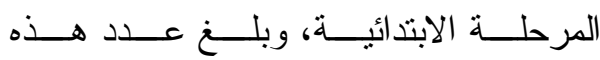

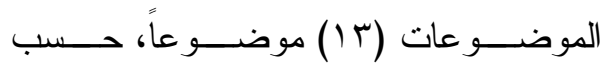

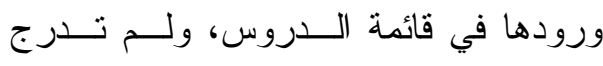
علامات الترقيم ضدن المهار ات، مـــع أنهــــا وردت ضمن مفـردات مقـررات (لغتــي الجميلة) للصفوف المذكورة؛ لأنها لا تتعلــق

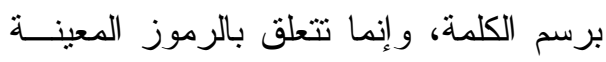

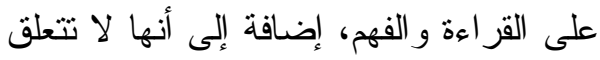

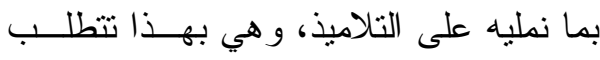

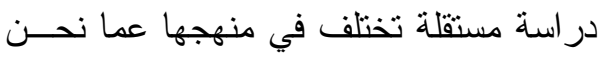
بصدده.

• عرض الاختبار على المحكمين: بعـــ

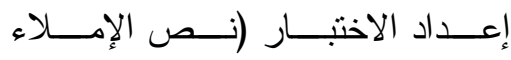
الاختباري) في صورته المبئية قــام الباحث بعرضنه على مجموعــة مــن فئن السادة المحكمين من المتخصصين في بعري المناهج وطــرق التــدريس، و اللغـــة العربيــة، وبعـــ معلمـــي (لغتــي

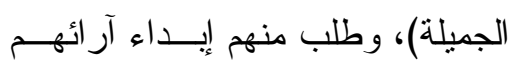

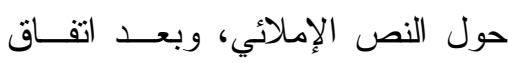
أغلبية المحكمين على مناسبة مستوى الهی

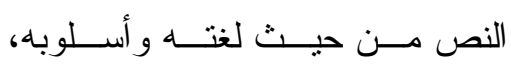

الصعوبات، وتحديــــ مــدى ملاعمنهــــا

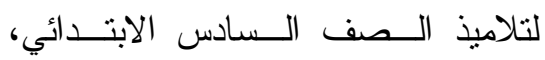

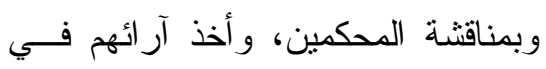
الاستبانة، انتهى الباحث إلى إجراء عدة الته تعديلات في القائمة.

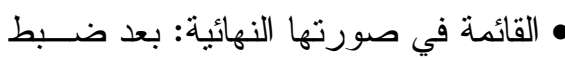
القائمة، ووضعت في صورتها النهائية،

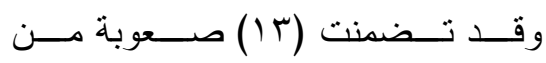

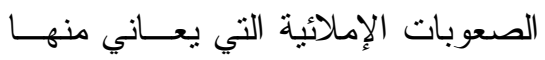
تلاميذ الصف السادس.

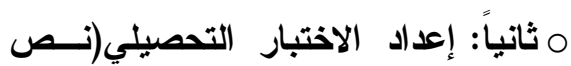
الإملاء الاختباري):

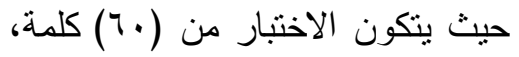

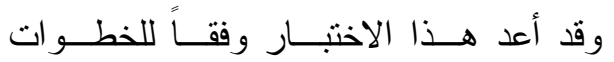
الإجر ائية التالية:

• تحديد الهدف من الاختبار :يهدف هــــال الاختبار إلى كثف مدى معاناة تلاميذ الصف السادس الابتدائي(عينة البحث)

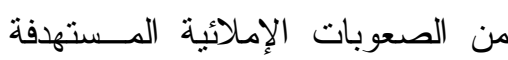
بالدراسة، وذلك من خلال الاختبـــار القبلي و البعدي. •صياغة الاختبار التحــصيلي (كتابـــة نص الإملاء الاختباري): اختار الباحث نصناً إملائيــاً متكــاملاً

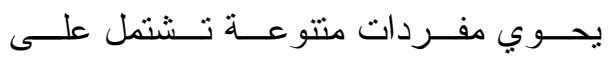

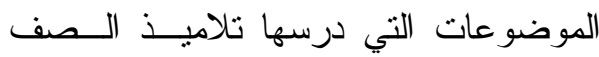

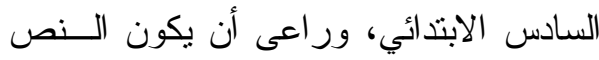

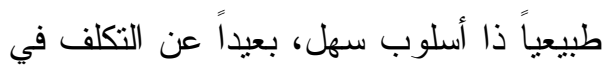


- يجمـــع الأوراق بطريقــة هادئــــة ومنظمة لتصحيحها.

• طريقة تقدير الدرجة فـــي الاختبـار :

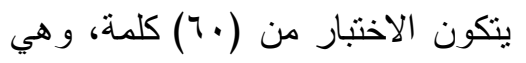

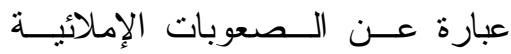
المستهدفة بالدر اسة، وحــد الباحــث درجة واحدة تعطى للإجابة الصحيحة لكل مفردة من مفردات الاختبار، في دالهاه

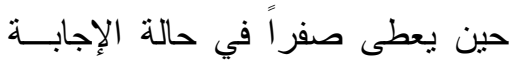
الخاطئة، ثم تقسم النتيجة على اثتـين؛ لكي تتفق مع الدرجة المحددة من قبل وز ارة التعليم، وهي ثلاثون درجة.

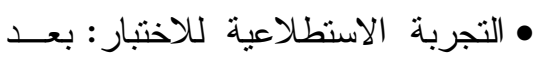

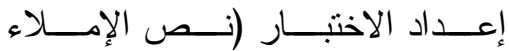

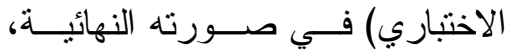
أجرى الباحث التجربة الاسـتنطلاعية للاختبار على عينة عشو ائية تكونـــت الات

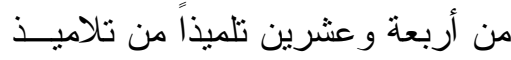
الصف السادس الابتدائي بمدرسة عبد

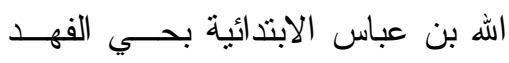
الثمالي في نجران، وذلك بغرض: - - تحديد زمن الاختبار - تحديد معامل السهولة و الصعوبة. - تحديد معامل ثبات الاختبار . - - تحديد معامل التمييز - تحديد معامل صدق الاختبار .
وملاءمته لتلاميذ الـصف الـسادس

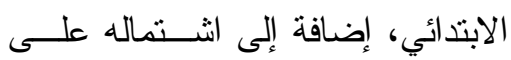

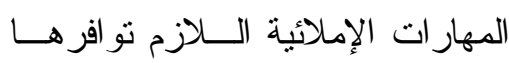
لدى تلاميذ الصف السادس الابتــدائي قام بالتعديل، و أصبح الاختبــار فــي لالـي صورته النهائية وصالحا للنطبيق.

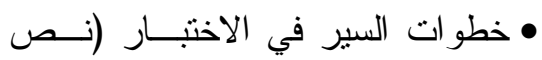
الإملاء الاختباري): - يمهد المعلم( الباحث) لنص الإملاء الإثلاء

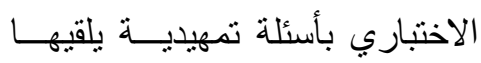
المعلـــم علـــى تلاميــذه؛ لإثـــارة انتباههم. - يقر أ المعلم (الباحث) نص الإمــلاء

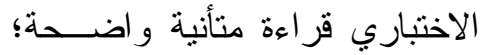
ليفهم التلاميذ فكرته العامة. - يناقش التلاميذ في المعنـى العـام

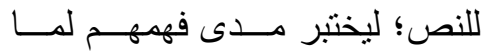
استمعوا إليه. - - يعيد قراءة النص علـــى التلاميـذذ؛ ليتهيؤو ا للكتابة. - يملي المعلم( الباحث) نص الإملاء الاختباري على التلاميذ في أور اقهم في وضوح وتأن. - يعيد قر اعة الـــص مــرة أخــرى؛ ليصلح التلاميذ ما وقعو ا فيه مسن أخطاء، أو ليتداركو ا ما فاتهم مسنـ نقص. 


$$
\begin{aligned}
& \text { • تحديد أهداف البرنامج: } \\
& \text { حدد الباحث أهداف البرنــامج، وقــــ } \\
& \text { جاءت كما يلي: } \\
& \text { - ضرورة توعيــة التلاميــذ بأهميـــة }
\end{aligned}
$$

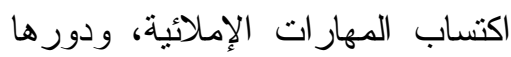

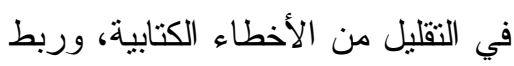

$$
\begin{aligned}
& \text { ذللك بحياتهم المهنية مستقبلا. } \\
& \text { ـ أهمية إكساب التلاميذ قو اعد الكتابـــة } \\
& \text { الإملائية الصحيحة. }
\end{aligned}
$$

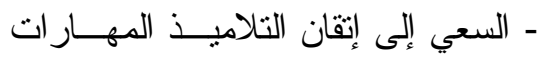

$$
\begin{aligned}
& \text { الإملائية، وتوظيفهــا فـــي كتابــاتهم }
\end{aligned}
$$

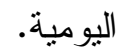

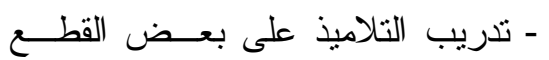

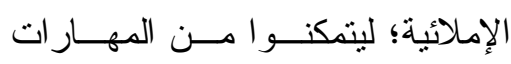

$$
\begin{aligned}
& \text { الإملائية اللازمة في مرحلتهم الحالية. } \\
& \text { • اختيار محتوى البرنامج: }
\end{aligned}
$$

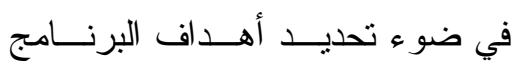

$$
\begin{aligned}
& \text { وضع محتو اه، وقد وضع البرنامج على هيئة }
\end{aligned}
$$

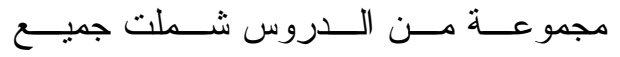

$$
\begin{aligned}
& \text { الصعوبات الإملائية المحددة فــي القائمسـة، }
\end{aligned}
$$

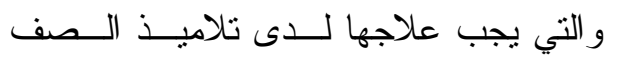

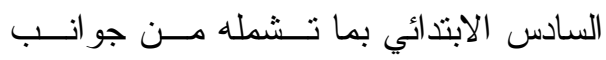

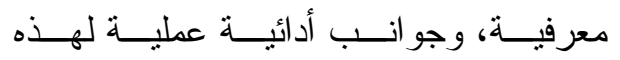

$$
\begin{aligned}
& \text { المهار ات. - ات } \\
& \text { • تحديد طر ائق تدريس البرنامج: }
\end{aligned}
$$

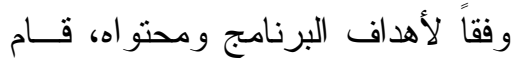

$$
\begin{aligned}
& \text { الباحث بتحديد طر ائق التدريس فــي ضــوء }
\end{aligned}
$$

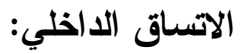

\begin{tabular}{|c|c|c|}
\hline \multicolumn{3}{|c|}{ الصعويات الاملانية. } \\
\hline الدلالة & الارتباط & المجال \\
\hline$\cdot,, \cdots)$ & •, УА५ & $\begin{array}{c}\text { الصتعلقة بالهوز ات } \\
\text { الصعات }\end{array}$ \\
\hline$\cdot, \ldots l$ & rדו, & المتعلقة بالحروف \\
\hline
\end{tabular}

$$
\begin{aligned}
& \text { تم حـساب الاتـساق الـــاخلي لأداة } \\
& \text { الدراسة الأساسية(نص الإملاء الاختبــاري) }
\end{aligned}
$$

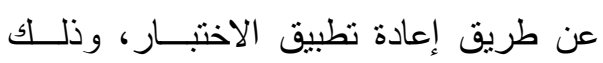

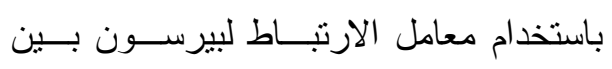

$$
\begin{aligned}
& \text { درجات التلاميذ على كل محور من محوري }
\end{aligned}
$$

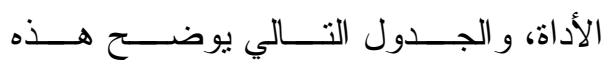

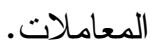

$$
\begin{aligned}
& \text { جدول ( } 1 \text { ) الاتساق الاخلي لاختبار }
\end{aligned}
$$




\begin{tabular}{|c|c|}
\hline • الأنشطة التعليميــة المـستخدمة فــي & 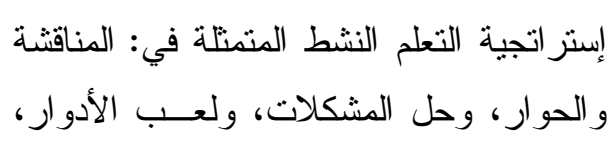 \\
\hline • تضمن البرنامج مجموعة من الأنشطة & و الـــتـعلم التعــــاوني، وتــــريس الأقــــران، \\
\hline التعليمية التي يؤديها التلاميــــ داخــل & و النمذجة، (الخليفة ومطاوع، 1 ( • Y) إضافة \\
\hline غرفة الصف وخارجها؛ للتأكد من مدى & إلى الأساليب التي تتاسب علاج الــصعوبات \\
\hline تجاوز التتلاميذ الــصعوبات الإملائيـــة & الإملائية المستهدفة من خلل أنشطة وظيفية \\
\hline المستهدفة، ومن هذه الأتــشطة:كتابـــة & هادفة ومنتو عة. \\
\hline التلاميذ بعض الكلمات على الـسبورة، & • الوسـائط التعليميــة المـستخدمة فــي \\
\hline وفي دفاتر الإملاء،وتـــصحيح التلاميـــذ & تحقيق أهداف البرنامج: \\
\hline أخطاءهم الإملائية بأنفسهم تحت إثر اف & حيث إن الوسائط التعليميــة تــسهل \\
\hline المعلم، وزيــارة المكتبــة المدرســية، & عملية التعليم على المعلــم، و الــتـعلم علــى \\
\hline و الاطلاع على بعض الكتب و القصص & التلميذ، وتحقق تتوعاً مرغوباً في الخبــرات \\
\hline فيها؛ لجمع كلمات ذات رســــ إملانـــي & التعليمية، ومن هذا المنطلق استخذم الباحــث \\
\hline معين. معين & بعض الوسائط التعليمية المعينة في تـــريس \\
\hline • أدوات تقويم البرنامج: & البرنامج ومنها: \\
\hline تضمن التقويم في هذا البرنامج عـدة & - جهـــاز الحاســب الآلـــي، وشاثــــة \\
\hline أسـاليب منها: التقــــيم المبــدئي، و التقــــيم & العرض؛ لعرض شرائح تعليمية على \\
\hline البنائي، و التقويم النهائي، كما استخدم التقويم & power التلاميذ بو اسطة برنـــامج \\
\hline الذاتي، وتثقيم الأقران، وقد تعددت وســائله & point توضح الجوانب المعرفية عن \\
\hline و أدو اته لتتشمل: & الصعوبات الإملائية المر اد علاجهــا، \\
\hline - طرح مجموعة من الأسئلة و التمــارين & و التقليل منها لدى التلاميذ. \\
\hline في أثنــــاء عــرض الــــروس، يجيــب & - بعض اللوحات الإيضاحية؛ لتوضـيـح \\
\hline عنها التناميـذذ؛ لــضمان تحقيـق كـــل & القو اعد المرتبطة ببعض الــصعوبات \\
\hline درس أهدافه، ولقيــاس مــدى اجتيـــاز & الإملائية. \\
\hline التلاميـــــــــــــــعوبات الإملائيـــــــة & - سبورة الفصل؛ ليتدرب التلاميذ علــى \\
\hline المستهدفة. & كتابة بعض الجمل الإملائية. \\
\hline
\end{tabular}


درجات تلاميــذ المجمــوعتين، الــضابطة و التجريبية في التطبيق القبلي فــي اختبــار

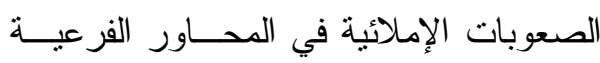

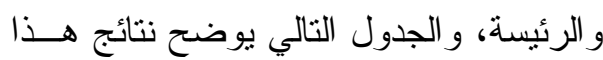

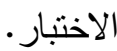

- - التطبيق القبلي لأداة الاراسة الأساسية: قُسمت عينة الدراسة إلى مجموعتين:

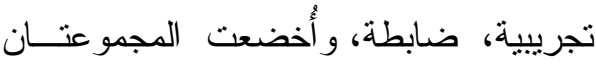
للاختبار القبلي من قبل الباحث قبل دراستهم

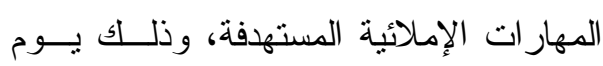

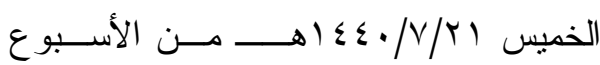

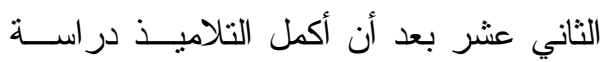

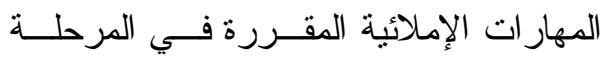
الابتدائية؛ للتحقق من تكــافؤ المجمـــوعتين

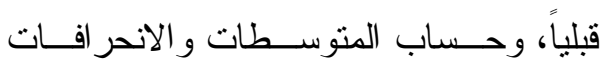

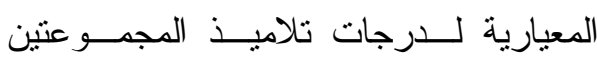
التجريبية والضابطة، ثم درست المجموعــة

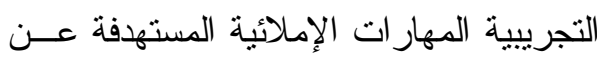
طريق البرنامج العلاجي، على مدى ثلاتـــة

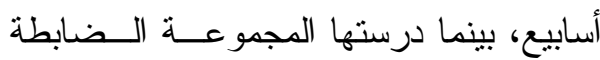
بالطريقة التقليدية. - - ت تلفيذ البرنامج:

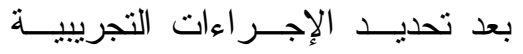
اللازمة لتتفيذ برنامج الدر اسة، و المتمتلة في

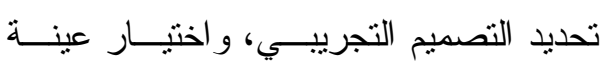

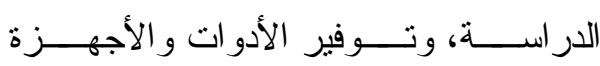

- المشاركة بأور اق عمل؛ لبيــان فاعليـــة

البرنامج في علاج الصعوبات الإملائية المستهدفة بالدر اسة.

- ملاحظة التلاميذ ومتـــابعتهم الدائـــة،

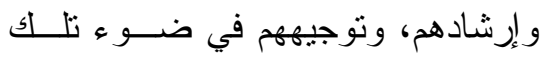

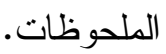
- إجر اء اختبار يتمثل في نــص إملائسـي

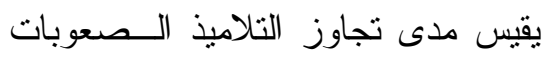
الإملائية المر اد علاجها. • تحكيم البرنامج العلاجي المقترح: بعـــ

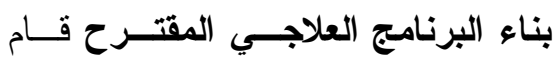
الباحث بعرضه على مجمو عة محكَّمـين من ذوي الاختصاص في اللغة العربيـــة

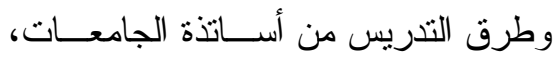
وطلب منهم إبداء الر أي في هذا البرنامج

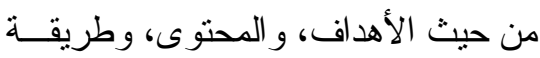
التذريس،و الوسائل التعليمية، و الأنــشطة وطنة

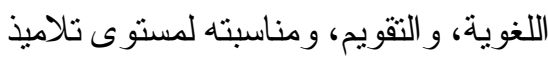

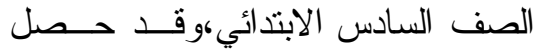
الباحث على بعض الآر اءو الملحوظــات

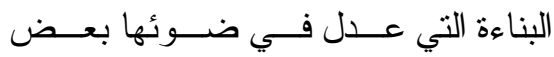

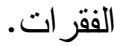
مرابعاً: خطوات تنفيذ الدراسة: • تكافؤ المجمو عنين قبلياً:

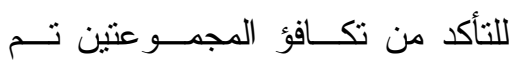

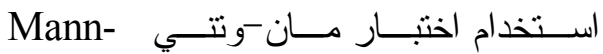
Whitney 
الاختباري على أفر اد المجموعتين؛ بهــدف رصد درجات التلاميذ للتطبيق البعدي، ثـم

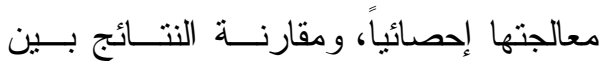
المجمو عتين، ومــن ثــم مناقـشـة النتــائج، و تقسير ها.

م الأساليب الإحــصائية المسـستخدمة فـي

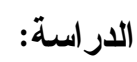

استخدم الباحث في هذه الار اسة الأســاليب الإحصائية الآتية:

- معامل ارنبــاط بيرســون لحـساب الاتساق الداخلي لأداة الدراسة(نــص

$$
\text { الإملاء الاختباري). }
$$

- معامل الفا لكرونباخ لحساب ثبات أداة

$$
\text { الدر اسة(نص الإملاء الاختباري). }
$$

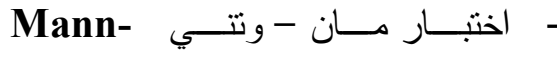
Whitney رتب درجــات تلاميــذ مجمــوعتي الدر اسة في كل محور مــن محــاور الأداة وفي الأداة ككل حيث أن عــدد كل مجمو عة يقل عن . آ. $r=\frac{z}{\sqrt{N}}$

- معامــلـل الفاعليـــة حيـــث الإحصاءة المستخدمة في اختبار مان - وتتي ، و N مجموع أعداد تلاميـــ المجمو عتين و هو رء تلمبذا.
و العروض التقديمية التــي يتطلبهـــا تتفيــذ البرنامج، وقد نفذ البرنامج وفق ما خطط له ، وقد حرص الباحث أثناء تتفيـــ البرنـــامج على الالتز ام بما بلي :

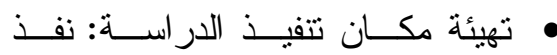
البرنامج في مركز مــصـادر الــتعلم

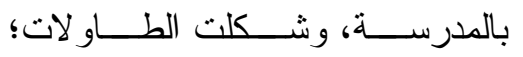
لتتناسب مع تتفيذ آلية البرنامج.

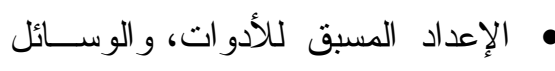

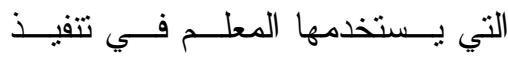

$$
\text { البرنامج. }
$$

توفير نسخ من أوراق الأنشطة لكـل تلميذ. • إثر الك جميع تلاميذ الفصل في تتفيذ خطو ات البرنامج. حرص الباحث قبل تتفيـــ البرنـــامج على شرح خطو ات التفيذ وإيــضـاح بعض التعليمات الخاصة بذلك.

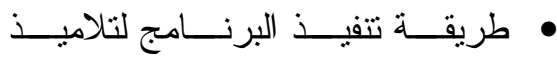
المجمو عة التجريبية حصة لشرح توفير حو افز مادية ومعنوية لتـشجيع

$$
\text { التحلاميذ }
$$

لأداة الأر اســــــة

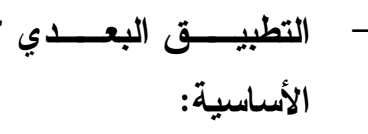
وبعد انتهاء الخطة الزمنيــة المحــددة لبرنـــامج عــــلاج الـــصعوبات الإملائيــــة المستهدفة، أعبــــ تطبيــق نــص الإمــلاء 


\begin{tabular}{|c|c|c|c|c|c|c|}
\hline مستوى & $\mathbf{Z}$ & متوسط & مجموع & العدد الع & المجموعة & المحاور الرئيسة والفرعية \\
\hline \multirow{2}{*}{$\cdot, \vee \vee}$. & \multirow{2}{*}{$\cdot$, r. ० } & $r r, q$. & $0 V Y, O$. & $r \varepsilon$ & الضابطة & \multirow{2}{*}{ هزتا الوصل و القطع } \\
\hline & & ro, I. & $7 . Y, 0$. & $r \varepsilon$ & التجرييية & \\
\hline \multirow{2}{*}{$\cdot, \varepsilon \vee \leqslant$} & \multirow{2}{*}{$\cdot, \vee \backslash \vee$} & $r T, I T$ & $000, \ldots$ & $r \varepsilon$ & الضابطة & \multirow{2}{*}{ الهمزة المنوسطة بأنو اعها الثلاثة } \\
\hline & & $r 0, \wedge \wedge$ & $7 Y 1, \cdots$ & $r \varepsilon$ & التجرييية & \\
\hline \multirow{2}{*}{$\cdot, \varepsilon \wedge r$} & \multirow{2}{*}{$\cdot, V \cdot r$} & $r r, I V$ & $007, \ldots$ & $r \varepsilon$ & الضابطة & \multirow{2}{*}{ الهمزة المتطرفة بأنو اعها الثلاثة } \\
\hline & & ro,Nr & $T \pi \cdot, \cdots$ & $r \varepsilon$ & التجرييية & \\
\hline \multirow{2}{*}{$\cdot, 9 \leq}$. & \multirow{2}{*}{$\cdot, \cdot \vee \vee 7-$} & $r \leqslant, 70$ & $091,0$. & $r \varepsilon$ & الضابطة & \multirow{2}{*}{ و المفتوحة التفريق بين التاء المربوطة } \\
\hline & & $r \varepsilon, r_{0}$ & $0 \wedge \varepsilon, 0$. & $r \varepsilon$ & التجرييية & \\
\hline \multirow{2}{*}{$1, \cdots$} & \multirow{2}{*}{$\cdot, \cdots$} & $r \leqslant, 0$. & $0 \wedge \Lambda, \cdots$ & $r \varepsilon$ & الضابطة & \multirow{2}{*}{ و الهاءم التفريق بين التاء المربوطة } \\
\hline & & $r \leqslant, 0$. & $0 \wedge \Lambda, \cdots$ & $r \varepsilon$ & التجرييية & \\
\hline \multirow{2}{*}{$\cdot, V \leqslant \Lambda$} & \multirow{2}{*}{$\cdot, T_{Y} \mid-$} & $r \varepsilon, \ldots$ & $0 \vee 7, \cdots$ & $r \varepsilon$ & الضابطة & \multirow{2}{*}{ عدم التفريق بين التتوين و النون } \\
\hline & & $r_{0, \ldots}$ & $7, \cdots, \cdots$ & $r \varepsilon$ & التجريبية & \\
\hline \multirow[b]{2}{*}{$\cdot, T \leq V$} & \multirow[b]{2}{*}{$\cdot$, • $0 \wedge-$} & Tr,T & $07 V, \ldots$ & $r \varepsilon$ & الضابطة & \multirow{2}{*}{ 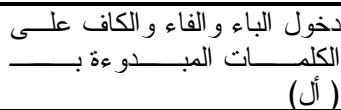 } \\
\hline & & ro, rᄉ & $7.9, \cdots$ & $r \varepsilon$ & التجريبية & \\
\hline \multirow{2}{*}{$\cdot, \Gamma 99$} & \multirow{2}{*}{$\cdot, \wedge \leq \Gamma-$} & Tr,AO & $0 \leqslant \wedge, 0$. & $r \varepsilon$ & الضابطة & \multirow{2}{*}{ حذف بعض الأحرف من الكلمة } \\
\hline & & $r 7,10$ & $T Y V, 0$. & $r \varepsilon$ & التجرييية & \\
\hline 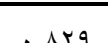 & r $17-$ & $r \varepsilon, \cdot \Lambda$ & $O \vee \wedge, \cdots$ & $r \varepsilon$ & الضابطة & 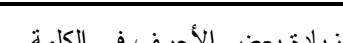 \\
\hline$\bullet, \wedge 17$ & $\cdot, 1,11^{-}$ & $r \varepsilon, 9 r$ & $091, \cdots$ & $r \varepsilon$ & التجريبية & رياده بعص الاحرق قي الحمه \\
\hline.$\leqslant \leqslant Y$ & - $V_{7} .-$ & $r r, \cdot \Lambda$ & $00 \leqslant, \ldots$ & $r \varepsilon$ & الضابطة & 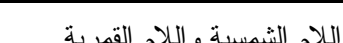 \\
\hline 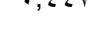 & & Yo, qY & TYY,.. & $r \varepsilon$ & التجرييية & "سم5 \\
\hline .771 &.$\leqslant$. & $r r, V I$ & $079, \ldots$ & $r \varepsilon$ & الضـابطة & لثلاثة \\
\hline ה & $\cdot, 2,7=$ & ro, rq & $7 \cdot V, \ldots$ & $r \varepsilon$ & التجريبية & المدود بالو اعها السالدة \\
\hline $.91 \mathrm{r}$ & ..Yr- & $T \leqslant, 0 \leqslant$ & $0 \wedge 9, \ldots$ & $r \varepsilon$ & الضابطة & دخــــول (ال) علــــى الكلمــــات \\
\hline • & & $r \leq, \leq T$ & $0 \wedge \vee, \ldots$ & $r \varepsilon$ & التجريبية & المبدو عة بأللام \\
\hline . $\Delta 7 \mathrm{~V}$ & $.17 \gamma-$ & $r\{, \wedge 1$ & $090,0$. & $r \varepsilon$ & الضابطة & كتابة الـــــاد بــصورة الظــــاء \\
\hline •,人 & $\cdot, 162-$ & $r \leqslant, 19$ & $01 \cdot, 0$. & $r \varepsilon$ & التجريبية & و العكس \\
\hline .7 .7 & $.017-$ & $r r, V$ & $079, \ldots$ & $r \varepsilon$ & الضابطة & إثثباع الفتحة ألفا والــضمة واوا \\
\hline$\cdot$, & & ro, rq & $T \cdot V, \ldots$ & $r \varepsilon$ & التجريبية & و الكسرة باء \\
\hline .7 .1 & .0 Orr & $r T, \Sigma \Lambda$ & $07 r, 0$. & $r \varepsilon$ & الضـابطة & \\
\hline$\cdot, \uparrow$, & $\cdot, 0 T T-$ & YO,OY & $71 Y, 0$. & $r \varepsilon$ & التجريبية & الالق اللينه بنو عيها \\
\hline .099 & . ory- & $r T, 0 \leq$ & $070, \ldots$ & $r \varepsilon$ & الضابطة & \\
\hline & & Y0, $\leqslant 7$ & $71, \ldots$ & $r \varepsilon$ & التجرييية & إبدال الحروق \\
\hline פ & $.977-$ & YY,TH & $0 \leqslant r, \cdots$ & $r \varepsilon$ & الضابطة & حذف ألف (ما ) الاستقهامية عند \\
\hline$\cdot, T T z$ & $\cdot, 477-$ & rT,rA & Trr,.. & $r \varepsilon$ & التجريبية & دخول حروف الجر عليها \\
\hline $.0 V_{4}$ & & $r T, \Sigma \varepsilon$ & $07 Y, 0$. & $r \varepsilon$ & الضابطة & دخول حرفي الجر (من ، عن ) \\
\hline & & Y0,07 & $71 r, 0$. & $r \varepsilon$ & التجريبية & على \\
\hline .074 & & rT, ro & $07 \cdot, 0$. & $r \varepsilon$ & الضابطة & \\
\hline$\cdot 0$ & $\cdot, 0 \mathrm{~V}$ & Y0,70 & $710,0$. & $r \varepsilon$ & التجريبية & محور الهمر ات حدل \\
\hline .0 .1 & . $171-$ & $r T, I V$ & $007, \ldots$ & $r \varepsilon$ & الضابطة & M \\
\hline & & YO,Ar & $\pi T_{\cdot, \cdot, \cdot}$ & $r \varepsilon$ & التجرييية & 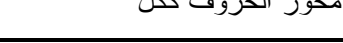 \\
\hline - $\{\Delta r$ & & $r r, \cdot \Lambda$ & $00 \leqslant, \ldots$ & $r \varepsilon$ & الضابطة & \\
\hline$\cdot, 2 \lambda 1$ & & ro, 9 r & $T Y Y, \ldots$ & $r \varepsilon$ & التجرييية & الاحتب \\
\hline
\end{tabular}


م الــصعوبات الإملائيـــة المتعلقـــة

بالهمزات، ويحتوي على (r) صعوبات

إملائية.

م الـــصعوبات الإملائيـــة المتعلقـــة

بــالحروف، ويسـضم (10) صــــوبة إملائية. - إنة.

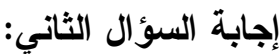

ينص السؤال الثاني على: ما التصور

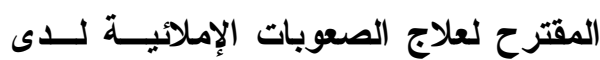
تلاميذ الصف السادس الابتدائي؟

وللإجابة عن هذا الـسؤال:وضــع

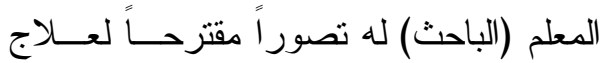

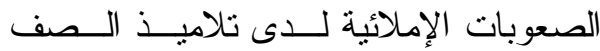

السادس الابتدائي حيث يقوم بــإملاء نــص

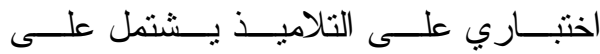

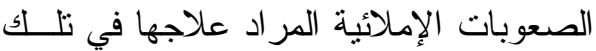

الحصة (حسب ورودها في قائمة الصعوبات

الإملائية المستهدفة، وحسب خطة البرنــامج

العلاجي) في حدود عثر دقائق، وفي حصة

أخرى بيتهدف صعوبات أخــرى جليــــة، وهكذا، وبعد تصحيح أوراق التلاميذ في كل مرة يقوم بحصر الأخطاء الإملائيـــة لــديهم سواء أكانت الأخطاء فردية أو جماعية، ثـــ

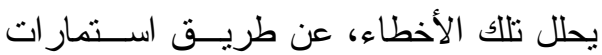
أعدت لهذا الغرض؛ لينوصل إلـى الإجابـــة

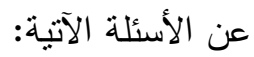

يتضح من الجدول السابق عدم وجود

فروق ذات دلالة إحصائية بين رثب درجات

تلاميذ المجمو عتين الضابطة و التجرييية فـي التطبيق القبلي لاختبار الصعوبات الإملائية، مما يشير إلى تكافؤ مجمو عتي الدراسة قبلياً

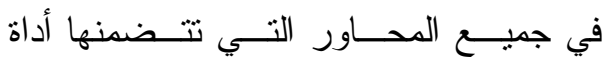
الدر اسة(نص الإملاء الاختباري).

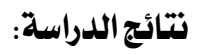

تتاول الباحث فيما يلي النتــائج التــي

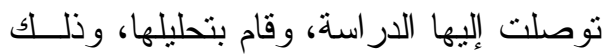
على النحو التالي: إجابة السؤال الأول:

ينص السؤال الأول للاراسة على:"مـــ

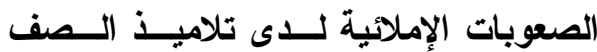
السادس الابتدائي بمدينة نجران"؟

وللإجابة عن هذا السؤال قام الباحــث

بإعداد قائمة مبدئية بالصعوبات الإملائية لدى لدى لهابه تلاميذ الصف السادس الابتدائي، وعرضـــها علـى مجموعـة مــن الـسادة المحكمـين المختصين في المناهج وطرق التدريس، وفي اللغة العربية وبعض معلمي (لغتي الجمياـــة)

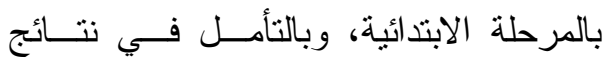

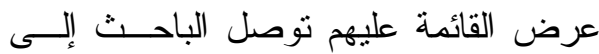

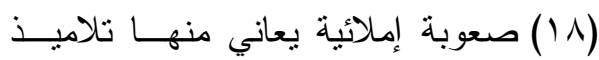

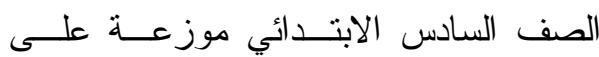
محورين هما: - ما: 
إلى نجمات إيجابية، تحت توجيه المعلم لكيلا

السؤال الأول: من أضعف التلاميذ فــي

يقع في تلك الأخطاء مرة أخرى، وفي نهاية

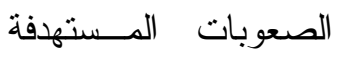

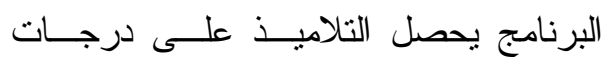

لتلك الحصة حسب خطة

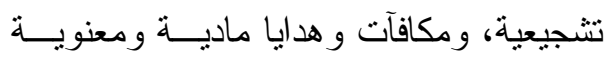

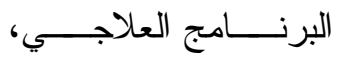

مقدمة من المعلم نظير تحسن مستو اهم.

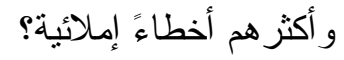

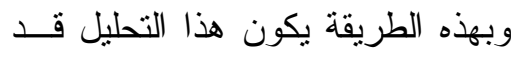

السؤال الثاني:مــــا أكثـــر الــصعوبات

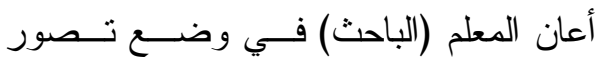

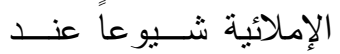

مقتـرح حيعـين البــاحثين علــى تـشخيص

التلاميذ في تلك الحصة؟

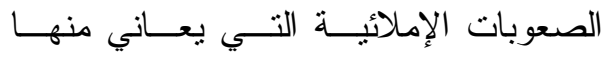

السؤال الثالث:ما الصعوبات الإملائيـــة

تلاميذهم، ووضع الحلول المناسبة لعلاجها،

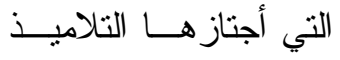

ويساعد التلاميذ على تجـاوز الــصعوبات

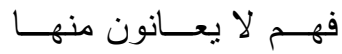

الإملائية التي كانو ا يتعثرون فيها.

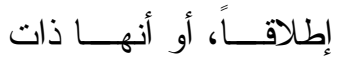

إجابة السؤال الثالث:

ينص السؤال الثالث للاراسة على:"مـــ

معاناة قليلة جداً بالنـسبة إنس

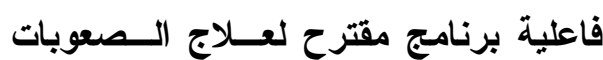

لهج?

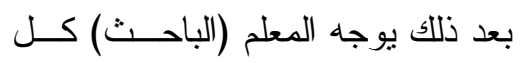

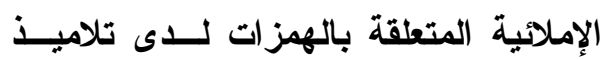

تلميذ من التلاميذ المستهدفين إلـى تـسجيل

الصف السادس الابتدائي بمدينة نجران؟" بانهزئ

أخطائه الإملائية، وذلك بالتأثنير تحت كـلــل

وللإجابة عن هذا السؤ ال تم حسساب

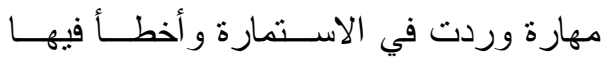

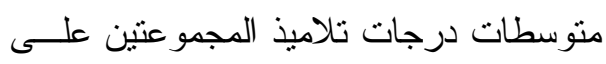

بالعلامة(×)، ثم يقوم بتصويب الأخطاء تحت

محور الهمزات في النطبيق البعدي للاختبار، مدئ

إثر اف المعلم، ويكرر التصويب حتى يـتنقن

و الثكل التالي يوضح هذه القيم.

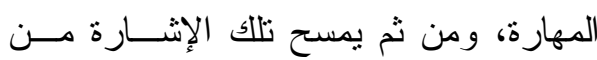

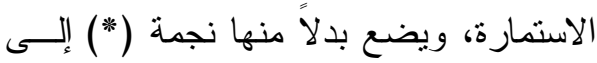

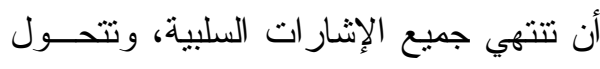




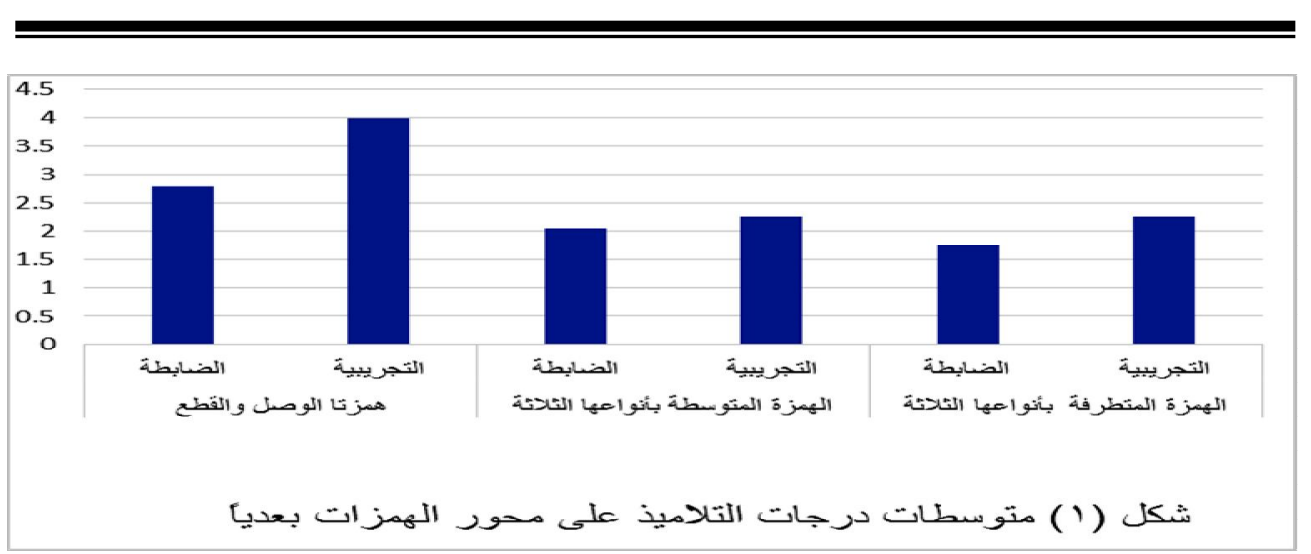

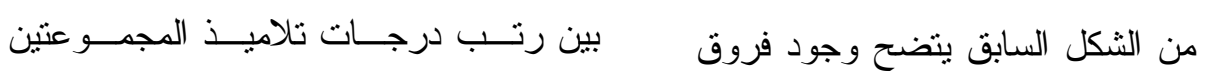

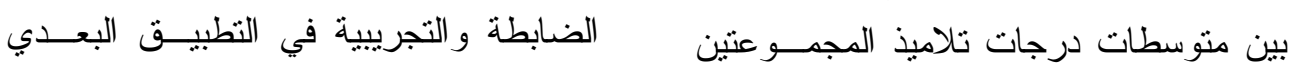

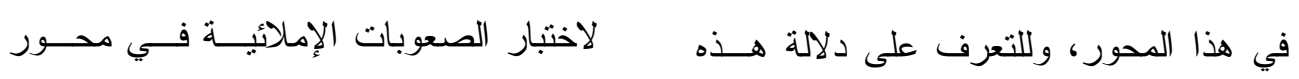

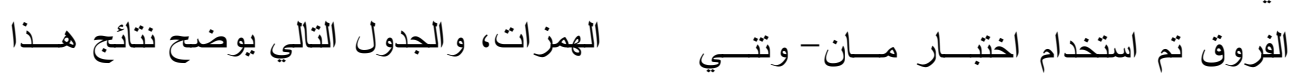
Mann- Whitney

\section{جدول(r)}

دلالة الفروق بين رتب درجات تلاميذ المجموعتين الضابطة والتجريبية في التطبيق البعدي لاختبار الصعوبات الإملاهية في محور الهمزات.

\begin{tabular}{|c|c|c|c|c|c|c|}
\hline مستوى الالاة & $\mathbf{Z}$ & متوسط & مجموع & 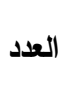 & المجموعة & محور الهمزات \\
\hline \multirow{2}{*}{0.003} & \multirow{2}{*}{3.005} & 18.58 & 446.00 & $r \leq$ & الضابطة & \multirow{2}{*}{ همزتا الوصل و القطع } \\
\hline & & 30.42 & 730.00 & $r \leq$ & التجرييية & \\
\hline \multirow{2}{*}{0.509} & \multirow{2}{*}{0.660} & 23.25 & 558.00 & $r \leq$ & الضابطة & \multirow{2}{*}{ 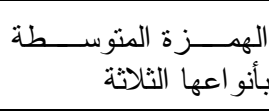 } \\
\hline & & 25.75 & 618.00 & $r \leq$ & التجرييية & \\
\hline \multirow{2}{*}{0.067} & \multirow{2}{*}{1.834} & 21.00 & 504.00 & $r \leq$ & الضابطة & \multirow{2}{*}{ 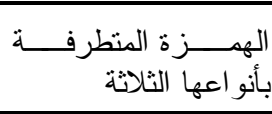 } \\
\hline & & 28.00 & 672.00 & $r \leq$ & التجرييية & \\
\hline \multirow{2}{*}{0.025} & \multirow{2}{*}{2.236} & 20.02 & 480.50 & $r \leq$ & الضابطة & \multirow{2}{*}{ محور الههزات ككل } \\
\hline & & 28.98 & 695.50 & $r \varepsilon$ & التجرييية & \\
\hline
\end{tabular}




\section{من الجدول السابق يتضح ما يأتي:}

وللتعرف علــى فاعليــة البرنــامج

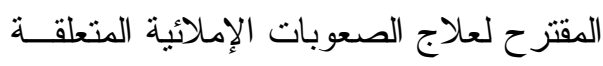

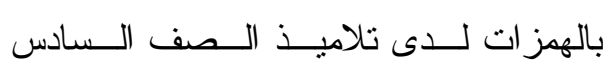
الابتدائي بمدينة نجر ان تم اســـتخدام معامـلـل

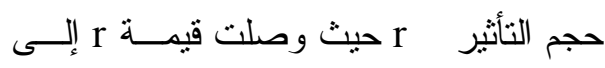

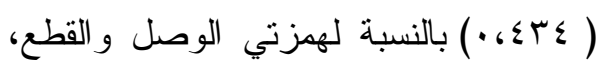

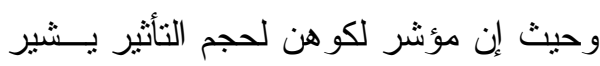

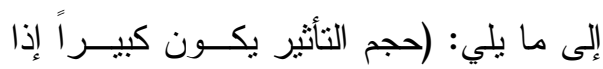

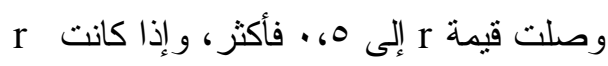

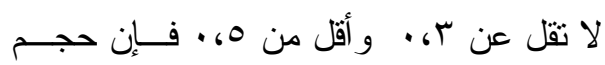

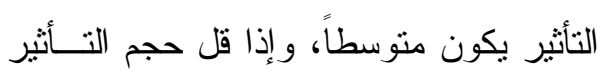

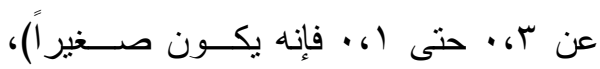

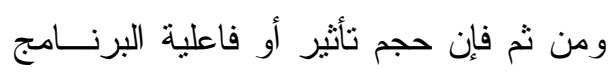

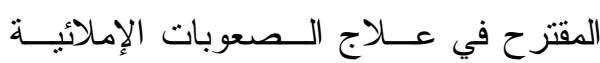
المتعلقة بهمزني الوصل و القطع جاء منوسطاً

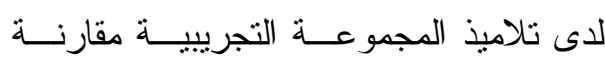
بتلاميذ المجموعة الضابطة.

وفيما يتصل بمحور الهمز ات كهـلـلـ

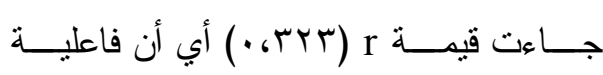

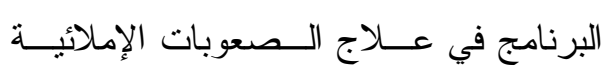
المتعلقة بمحور الهمز ات ككل كانت منوسطة

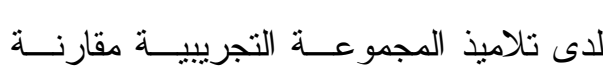
بتلاميذ المجموعة الضابطة.

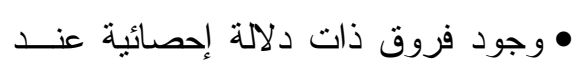

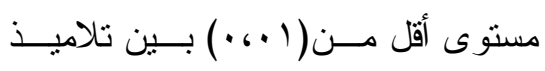

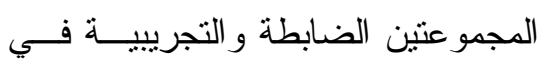

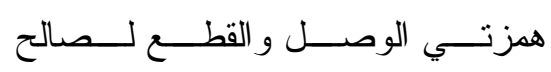

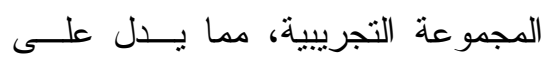

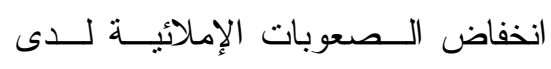
تلاميذ المجموعــة التجريبيــة مقارنــــة بتلاميذ المجموعة الضابطة فــي كتابــة هزني الوصل و القطع. • عدم وجود فروق ذات دلالة إحــصائية

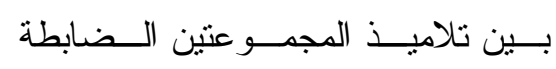

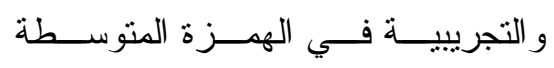

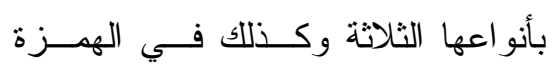

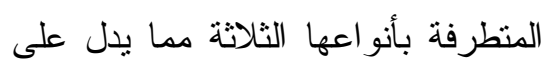

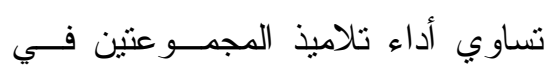
هذين المحورين الفرعيين.

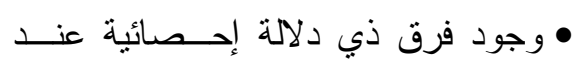

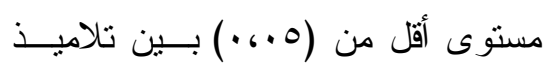

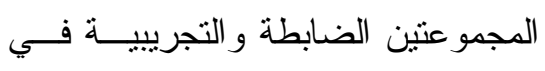

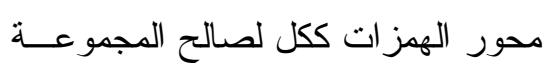

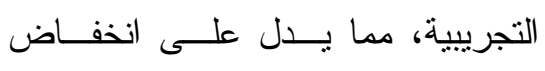

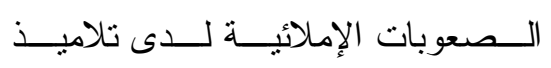

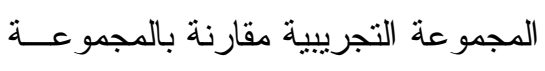

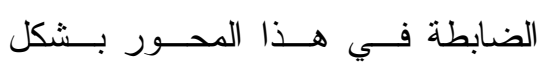
عام. 
وللإجابة عن هذا السؤال نم حسساب

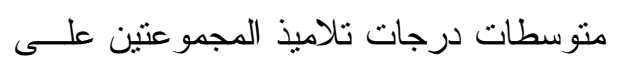
محور الحروف في التطبيق البعدي للاختبار و الثكل التالي يوضح هذه القيم.
إجابة السؤال الرابع:

ينص السؤال الرابع للاراسة على"ما

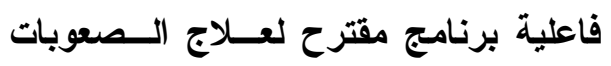

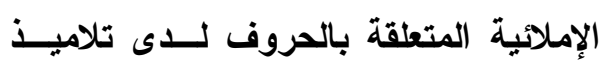
الصف السادس الابتدائي بمدينة نجران؟ بالئه

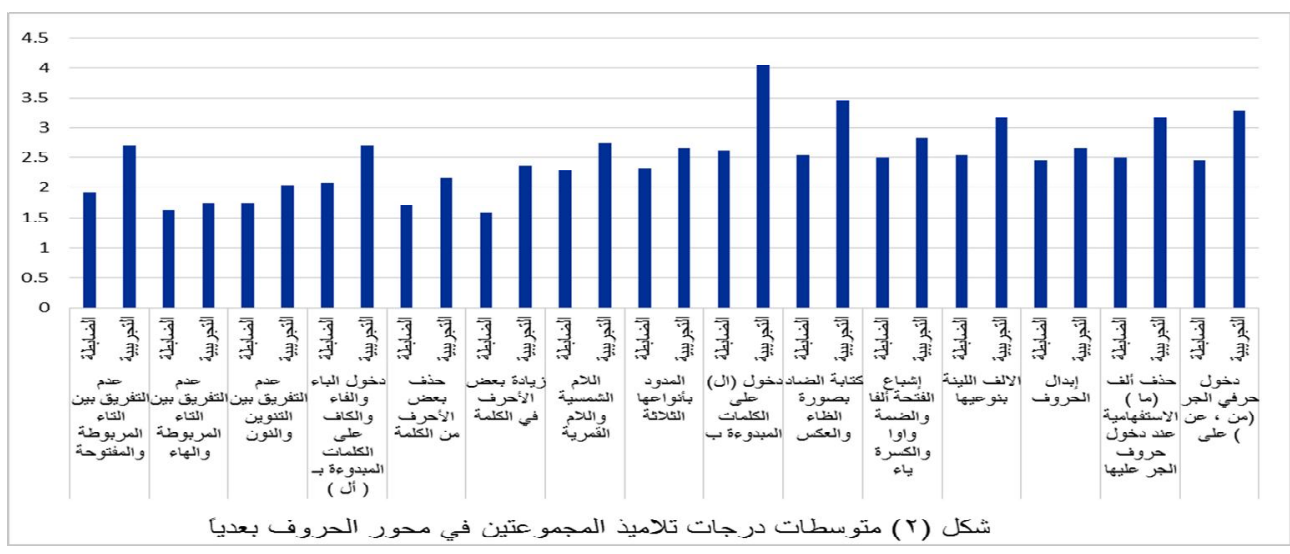

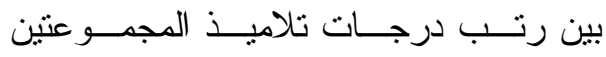
من الشكل السابق يتضح وجود فــروق الضابطة و التجريبية في التطبيــق البعـدي رئدي بين متوسطات درجات تلاميذ المجمــوعنين لاختبار الصعوبات الإملائيــة فــي محسـور

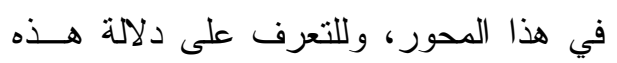

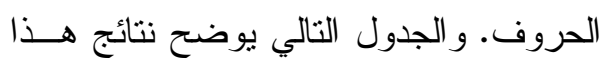

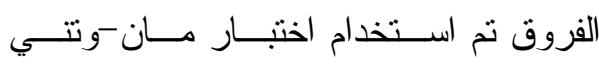
Mann- Whitney 


\begin{tabular}{|c|c|c|c|c|c|c|}
\hline مستوى & $\mathbf{Z}$ & متوسط & 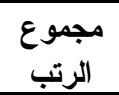 & العدد & المجموعة & المحاور الرئيسة والفرعية \\
\hline \multirow{2}{*}{$\cdot, \cdots \varepsilon$} & \multirow{2}{*}{$r, q \cdot T$} & 19,19 & $\leq 7,0$. & $r \varepsilon$ & الضابطة & \multirow{2}{*}{ و عدم التفريق بين التاء المربوطة } \\
\hline & & $r q, \wedge)$ & $V 10,0$. & $r \varepsilon$ & التجرييية & \\
\hline \multirow{2}{*}{$\cdot, \vee \vee 1$} & \multirow{2}{*}{ • } & YT,97 & ovo,... & $r \varepsilon$ & الضابطة & \multirow{2}{*}{ و الهاء التفريق بين التاء المربوطة } \\
\hline & & ro,,$\varepsilon$ & $7,1, \ldots$ & $T \varepsilon$ & التجربيية & \\
\hline \multirow{2}{*}{$\cdot, \cdots 7$} & \multirow{2}{*}{ T,VYV } & r & $0 . v, \ldots$ & $r \varepsilon$ & الضابطة & \multirow{2}{*}{ عدم التفريق بين التتوين و النون } \\
\hline & & $r V, \wedge \Lambda$ & $779, \ldots$ & $T \varepsilon$ & التجريبية & \\
\hline \multirow{2}{*}{$\cdot, \cdot 1 r$} & \multirow{2}{*}{ r,or. } & $r \cdot, \ldots$ & $\varepsilon \wedge \cdot, \ldots$ & $T \varepsilon$ & الضابطة & \multirow{2}{*}{ 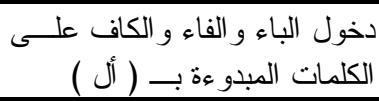 } \\
\hline & & $r q, \ldots$ & $797, \ldots$ & $r \varepsilon$ & التجرييية & \\
\hline \multirow{2}{*}{$\cdot, r \backslash \Lambda$} & \multirow{2}{*}{ אזr, } & $r, I r$ & or $1, \ldots$ & $r \varepsilon$ & الضابطة & \multirow{2}{*}{ حذف بعض الأحرف من الكلمة } \\
\hline & & $r \uparrow, \wedge \wedge$ & $7 \leqslant 0, \ldots$ & $T \varepsilon$ & التجريبية & \\
\hline \multirow{2}{*}{$\cdot, \cdot 1 \mathrm{~V}$} & \multirow{2}{*}{ r,rN } & $19,9 \leq$ & $\Sigma \vee \wedge, 0$. & $T \varepsilon$ & الضابطة & \multirow{2}{*}{ زيادة بعض الأحرف في الكلمة } \\
\hline & & $r q, \cdot 7$ & $79 \vee, 0$. & $r \varepsilon$ & التجريبية & \\
\hline \multirow{2}{*}{$\cdot, \cdot \leq q$} & \multirow{2}{*}{1,971} & 41,19 & $0.1,0$. & $T \varepsilon$ & الضابطة & \multirow{2}{*}{ اللام الشمسية و اللام القمرية } \\
\hline & & $r V, \Lambda I$ & TTV,O. & $r \varepsilon$ & التجريبية & \\
\hline \multirow{2}{*}{ 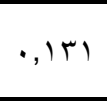 } & \multirow{2}{*}{$1,0.9$} & r),9r & ort, . & $r \varepsilon$ & الضابطة & \multirow{2}{*}{ المدود بأنو اعها الثناثة } \\
\hline & & $r v, \cdot A$ & $70, \ldots$ & $r \varepsilon$ & التجريبية & \\
\hline \multirow{2}{*}{$\cdot, \cdots$} & \multirow{2}{*}{$\varepsilon, 11 \wedge$} & $17, \varepsilon Y$ & एq々,... & $T \varepsilon$ & الضابطة & \multirow{2}{*}{ 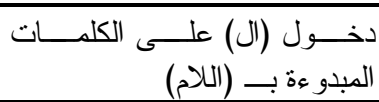 } \\
\hline & & rY,ON & VAr,... & $T \varepsilon$ & التجرييية & \\
\hline \multirow{2}{*}{$\cdot, \cdots$} & \multirow{2}{*}{ r,or } & $I V, V V$ & $\leqslant Y \uparrow, 0$. & $T \varepsilon$ & الضابطة & كتابة الــــاد بــصورة الظـــاء \\
\hline & & r & $v \leqslant 9,0$. & $r \varepsilon$ & التجريبية & و العكس \\
\hline $0 \leqslant<$ & 7.7 & $r T, T V$ & $071, \ldots$ & $r \varepsilon$ & الضابطة & إثثباع الفتحة ألفاً و الــضمة واو اً \\
\hline$\theta, 0=2$ & 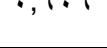 & r r & $\neg \cdot \wedge, \cdots$ & $r \varepsilon$ & التجرييية & و الكسرة باءً \\
\hline 0 & 197 & $r \cdot, V)$ & $\varepsilon q \vee, \ldots$ & $r \varepsilon$ & الضابطة & لألما الرنة \\
\hline 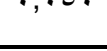 & 1,112 & $r \wedge, r q$ & $7 \vee 9, \ldots$ & $r \varepsilon$ & التجرييية & الاله \\
\hline IV & م س & $r Y, Y)$ & orr,... & $r \varepsilon$ & الضابطة & $\pi$ \\
\hline 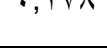 & $1,1<0$ & $r 7, \vee q$ & $r \leq r, \ldots$ & $r \varepsilon$ & التجرييية & \\
\hline & r ros & $r \cdot, I V$ & $\varepsilon \wedge \varepsilon, \ldots$ & $r \varepsilon$ & الضابطة & حذف ألف (ما ) الاستقهامية عند \\
\hline $9,+12$ & 1,102 & r৯,^r & $79 r, \ldots$ & $r \varepsilon$ & التجريبية & دخول حروف الجر عليها \\
\hline$\ldots$ & ryro & 19,r & $\varepsilon\rceil \varepsilon, \ldots$ & $r \varepsilon$ & الضابطة & دخول حرفي الجر (من ، عن ) \\
\hline$\cdot, \cdots$ & $1, n, 0$ & $r q, 7 V$ & $V I r, \ldots$ & $r \varepsilon$ & التجرييية & على مَن ع" \\
\hline..$r$ & r. & $|1, r|$ & $\varepsilon r q, 0$. & $r \varepsilon$ & الضابطة & \\
\hline & & $r \cdot, 79$ & VMT,0. & $T \varepsilon$ & التجريبية & محور الحرو \\
\hline
\end{tabular}


التاء المربوطة و الهاء، حسذف بعـض

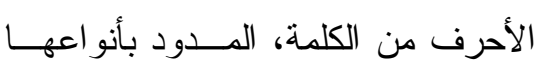

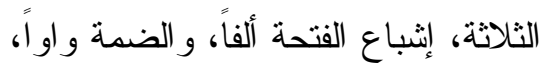
و الكسرة ياءة، إبدال الحروف) مما يسـدل على تساوى أداء تلاميذ المجموعتين في هذه المحاور الفرعية. •وجود فروق ذوات دلالة إحصائية عنــــ

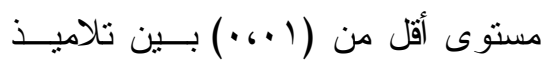

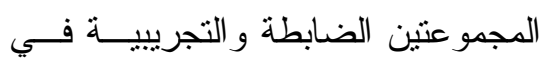
محور الحروف ككل لصالح المجموعة

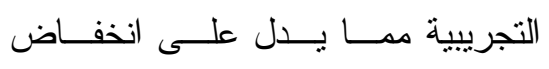

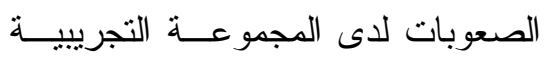

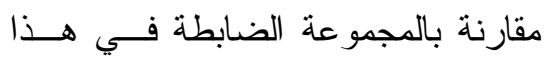
المحور بشكل عام.

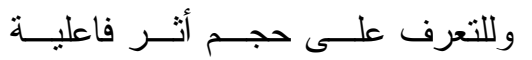

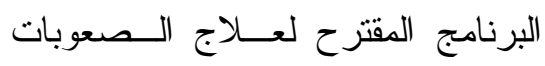
الإملائية المنعلقة بالحروف لدى تلاميــذ

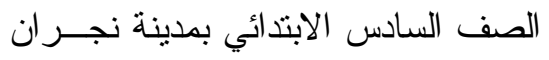

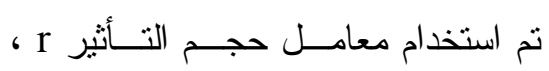
و الجدول التالي يوضح قيم هذه المعامل.

\section{من الجدول السابق يتضح ما يأتي:}

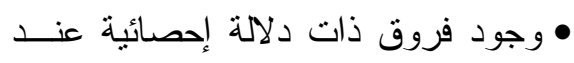

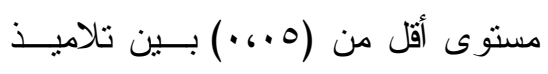

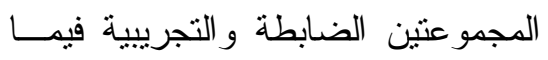

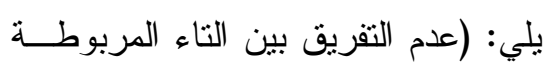

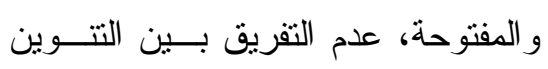

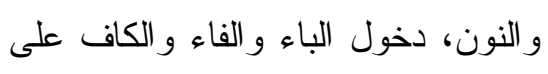

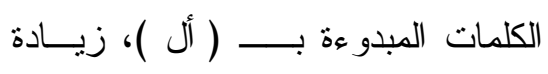
بعض الأحرف في الكلمة، اللام الثمسية و اللام القمرية، دخول (ال) على الكلمات

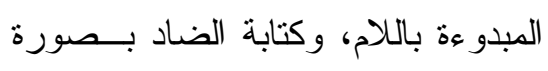

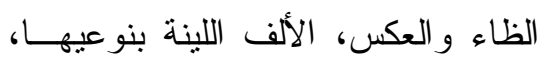

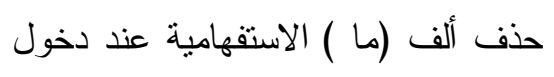

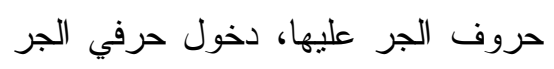
(مِنْ ، عــن ) علــى (مَـنْ) لــصالح

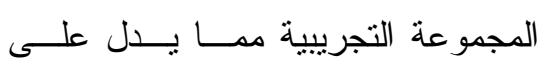

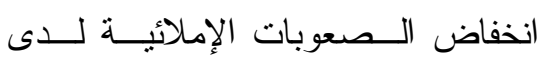

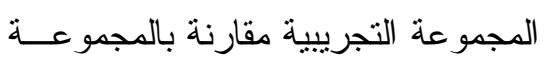
الضابطة في هذه المحاور • • عدم وجود فروق ذوات دلالة إحصائية

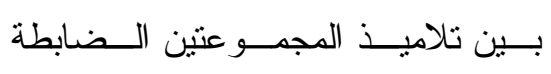
و التجرييية فيما يلي: (عدم التفريق بـين 
جدول (•) حجم تأثير البرنامج المقترح لعلاج الصعوبات الإملاية المتعلقة بالحروف

\begin{tabular}{|c|c|c|c|}
\hline حجم التأثير & 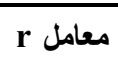 & $\mathbf{Z}$ & 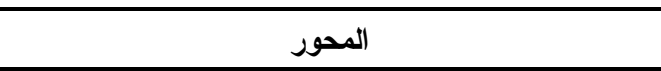 \\
\hline متوسط & $\cdot, \leqslant 19$ & r,q.१ & عدم التقريق بين التاء المربوطة و المفتوحة \\
\hline 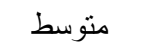 & $\cdot, r 9 \leq$ & T,VTV & عدم التفريق بين النتوين و النون \\
\hline 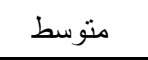 & • & r,or & دخول الباء و الفاء و الكاف على الكلمات المبدوءة بـــ( أل ) \\
\hline متوسط & $\cdot, r \leqslant \varepsilon$ & $r, r \wedge l$ & زيادة بعض الأحرف في الكلمة \\
\hline صغير & $\cdot, \Upsilon \wedge \wedge \varepsilon$ & 1,971 & اللام الثمسية و اللام القمرية \\
\hline كبير &., $09 \leqslant$ & $\varepsilon, 111$ & دخول (ال) على الكلمات المبدو عة باللام \\
\hline كبير &., 01. & r,orl & كتابة الضاد بصورة الظاء و العكس \\
\hline 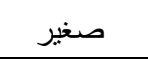 & • rAT & $1,97 \varepsilon$ & الألف اللينة بنوعيها \\
\hline متوسط & . rro & r, ros & عليها ألف (ما ) الاستفهامية عند دخول حـروف الجـر \\
\hline 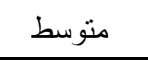 & $\cdot, 490$ & r,vro & دخول حرفي الجر (من ، عن ) على(مَن) \\
\hline 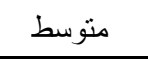 & •, & $r, \cdot{ }^{\prime}$ & محور الحروف ككل \\
\hline
\end{tabular}

من الجدول السابق يتضح أن البرنــامج إجابة السؤال الخامس:

ينص السؤال الخامس للارسة على:"ما

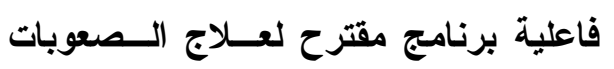

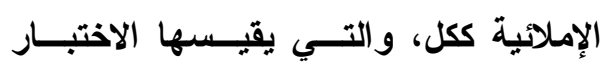

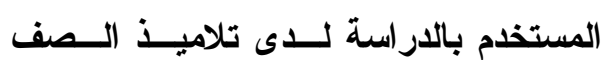

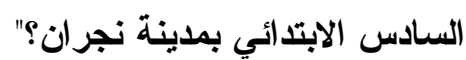

وللإجابة عن هذا السؤال تـم حسساب

متوسطي درجات تلاميذ المجمو عتين علـى هلى

الاختبار ككل في التطبيق البعدي للاختبـــار

و الثكل التالي يوضح هذه القيم.
المقترح فعال بدرجـــة كبيــرة فــي عــلاج الصعوبات الإملائية الخاصة(بكتابة الــضاد الـادية بصورة الظاء و العكس)، ودخول (أل) علــى الإنى

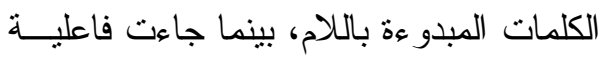
البرنــامج المقتــر ح صـــيرة فــي عــلاج الصعوبات الإملائية الخاصة بـــــــــــام الــام

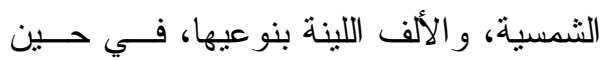
جاءت فاعلية البرنامج منوسطة فــي بقيـــة

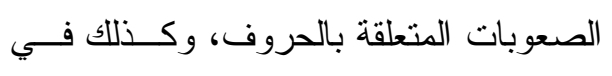
علاج الصعوبات الإملائية المتعلقة بالحروف بالهروفي كکل. 


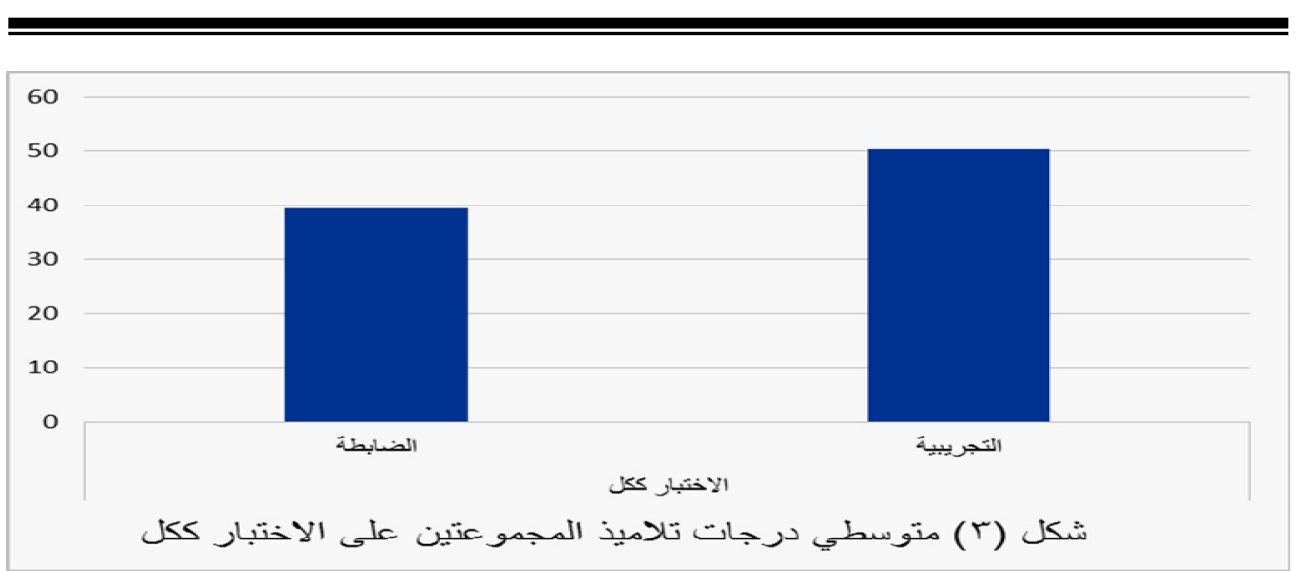

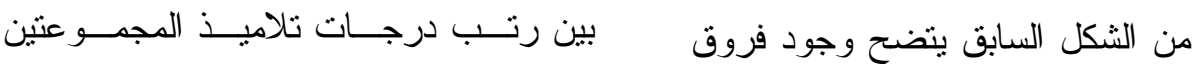

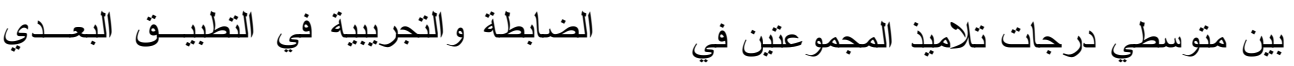

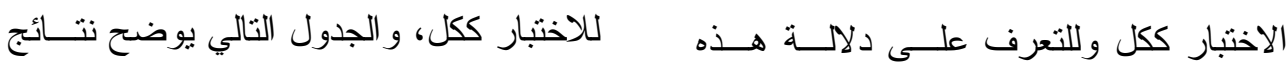

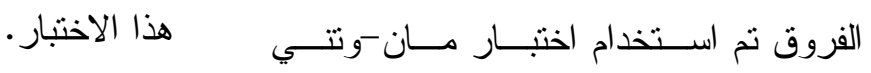
Mann- Whitney

جلول (ج) دلالة الفروق بين رتب درجات تلاميذ المجموعتين الضابطة، والتجريبية في التطبيق البعدي لاختبار الصعوبات الإملانية في الاختبار ككل.

\begin{tabular}{|c|c|c|c|c|c|c|}
\hline مستوى الدلادة & $\mathbf{Z}$ & متوسط الرتب & مجموع & العدد & المجموعة & البيان \\
\hline \multirow{2}{*}{$\cdot, \ldots \varepsilon$} & \multirow{2}{*}{$r, A Y)$} & $\varepsilon \leqslant q, \ldots$ & $|\Lambda, v|$ & $r \varepsilon$ & الضابطة & \multirow{2}{*}{ الاختبار ككل } \\
\hline & & $V r V, \ldots$ & $r \cdot, r q$ & $r \varepsilon$ & التجريبية & \\
\hline
\end{tabular}

وللتعــرف علــى فاعليــة البرنــامج

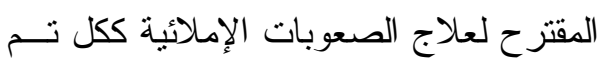

استخدام معامل حجم التأثنر r ميث جاءت

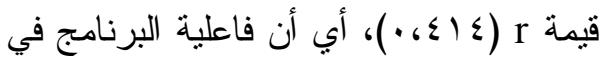

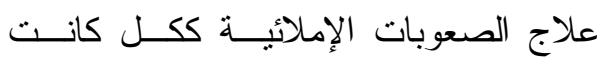

منوسطة لاى تلاميذ المجموعـــة التجريبيـــة مقارنة بتلاميذ المجمو عة الضابطة.
يتضح من الجدول السابق وجود فرق

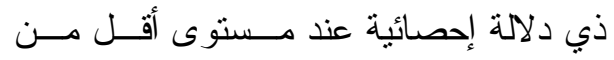
(1 +.، •) بين تلاميذ المجموعتين الــابطة

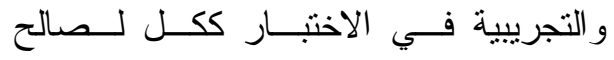

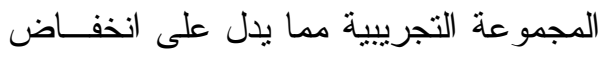

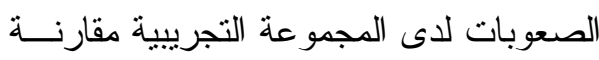
بالمجموعة الضابطة في الاختبار ككل بشكل

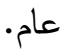


التلاميذ،وطبقو ها عملياً، فأصبحت سهلة

عليهم، بينما جاءت فاعليــة البرنــامج • أظهرت نتائج السؤال الثالث من الدراسة

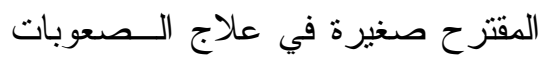
الحالية انخفاض الــصعوبات الإملائيــة الإملائية الخاصة بــــــــاللام الثمسية، لدى تلاميذ المجموعة التجريبية مقارنة و الألف اللينة بنو عيها، فيرجع الباحــث بـاث بالمجموعة الضابطة في كتابة همزتـي لئي

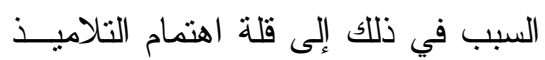
بهذه الصعوبة ظناً منهم أنهم أثقونها في

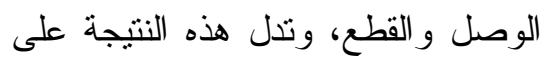
أن الصعوبات الإملائية المتعلقة بهزتي وهني الصف الثالث الابتدائي، وقد اختلفت هذه

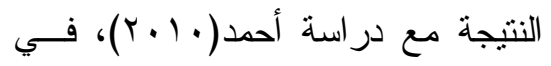

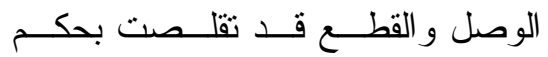
حين جاءت فاعلية البرنامج منوسطة في دريه اختلاف الطريقة المستخدمة، حيث يتعلم التنلاميذ ذوي الفهم المتوسط و المنخفض

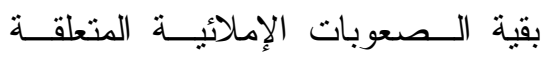
من التلاميذ ذوي التحصيل العالي، وهذا بالحروف، وكذلك في علاج الصعوبات الإملائية المتعلقة بالحروف ككل.

وبناءً على ما تقدم أظهــرت النتــائج ينعدم في الطريقة التقليدية، و هذه النتيجة

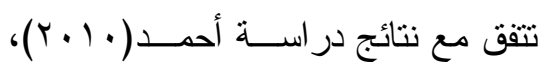

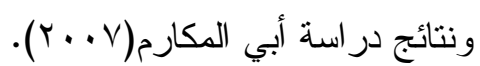

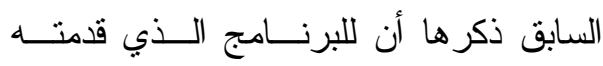

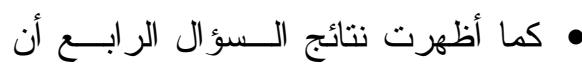

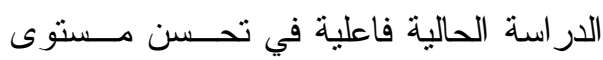
البرنامج المقترح فعال بدرجة كبيرة في التلاميذ في الصعوبات الإملائية المستهدفة

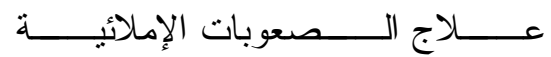

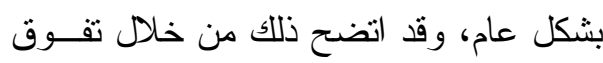
الخاصة(بكتابة الضـاد بــصورة الظـــاء تلاميذ المجموعة التجريبية في القياس البعدي و العكس)، ودخول (أل) على الكلمـات

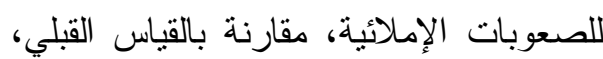

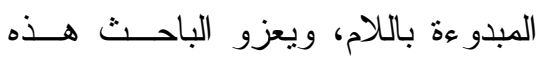
ومقارنة بالقياس البعدي لتلاميذ المجموعـــة النتيجة إلى كثرة التذريبات الـسبورية،

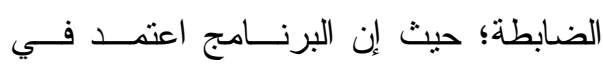

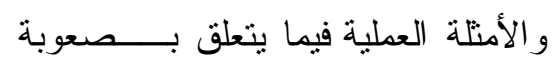

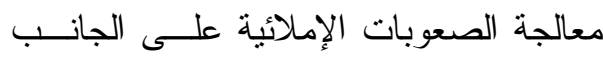
دخول(أل) على الكلمات المبدو عة باللام، ولمانه

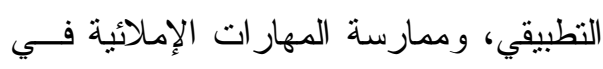
أما فيما يتعلق بكتابة الــضاد بــصورة

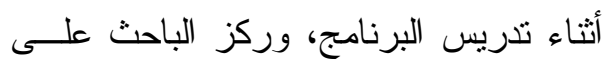
الظاء و العكس فيرجع إلى حصر الباحث

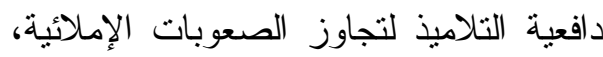

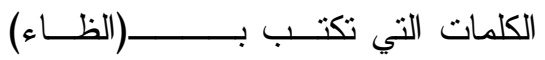
و إثنعار هم بأهمية تلك المهار ات، وضــــرورة

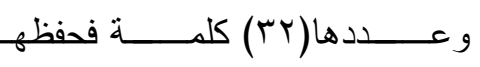


تمثيل الأدوار التي مكنتهم من التطبيق الجيد

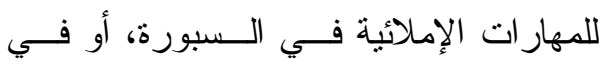

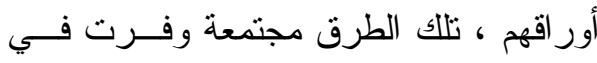
العملية التعليمية للبرنامج المتعة، وحب التعلم بعيداً عن الملل و التلقين و الاستظهار ، و وهــــا

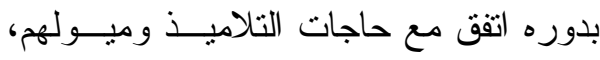
ومما ز اد من فاعلية هذا البرنامج العلاجـي

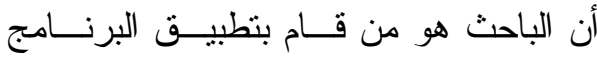

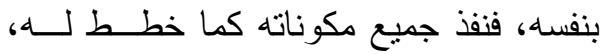
فرفع ذلك من كفاءة البرنامج، وفعاليته. وبذللك يمكن القول بأن هذه الدر اســـة،

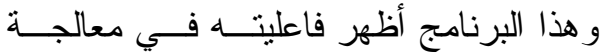

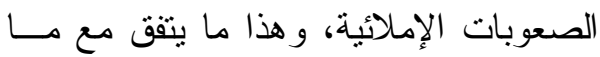

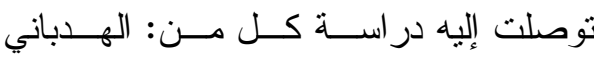
(T)

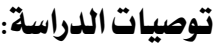

في ضوء هـ ما أسفرت عنــــه الدر اســـة الحالية من نتائج فإنها توصي بما يلي: - - الاســتفادة مــن البرنــامج العلاجـي المقترح، ووضعه موضع التنفيذ؛حيث يطبقه معلمو اللغة العربيــة بالمرحلـــة الابتدائية، على تلاميذهم؛ ليـسـاعدو هم

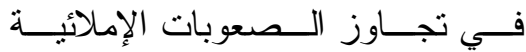
المستهدفة في البرنامج. - - - ضرورة إثرالك معلمي المواد الأخرى

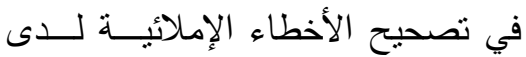

التمكن من ممارستها بشكل صـــيح؛ ممــــا

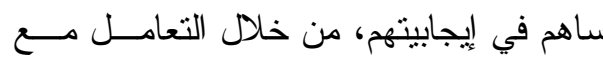
محتوى البرنامج العلاجـي، ومسـن خـــله

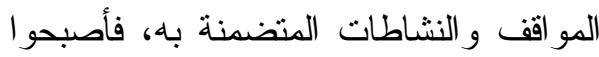

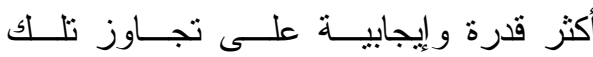

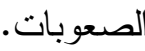

ويعزو الباحث هذه النتائج الإيجابيـــة

للار اسة بالإضـافة مــا ســـق إلــى إثـــراء المحتوى المعرفي المقدم في كل درس مسن دروس البرنـــامج، حيــث عــرَف الباحسـث

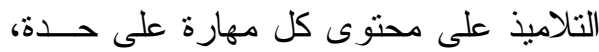
بصورة منفصلة، وتأكد من فهمه للجانــبـ

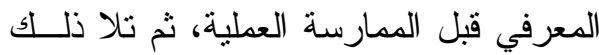

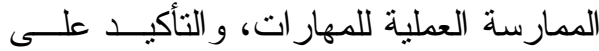
أدائهم الجيد لها، كما لم ينتقل من تعلم مهارة إلى تعلم مهارة أخرى دون التأكد من إلمــام

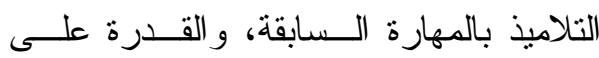
تطبيقها، و التدرب عليها بصورة فرديــة أو بـ جماعية، وكان للحرص على تـــوع طــرق التدريس المستخدمة من قبل المعلم (الباحث) وهن في تدريس المهارات الإملائية دور كبير في

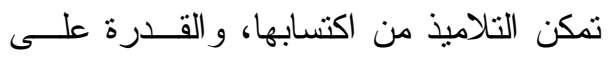

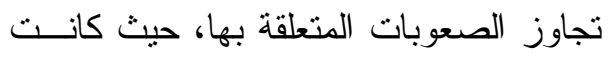

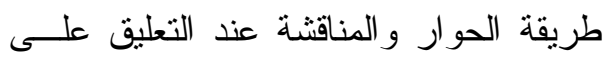

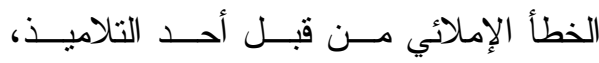

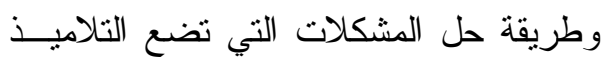
في مو اقف محيرة تثثر تفكيـر هم، وطريقــة 
التدريس الفعــال. الـــدمام: مكتبــة

$$
\text { المتتبي. }
$$

الخليفة، حسن جعفر ؛ ومطاو ع، ضياء الدين

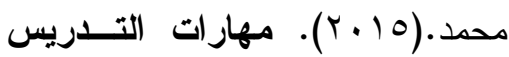

الفعال جودةً للتعليم و إتقاناً للــتعلم.

$$
\text { الرياض: مكتبة الرشد. }
$$

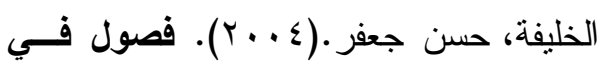

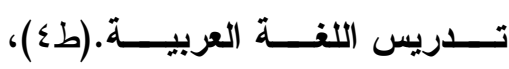
الرياض: مكتبة الرشد.

الربعي، محمد عبد العزيز؛ وصالح، هـــى

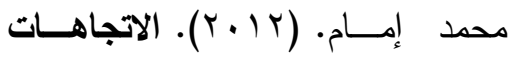

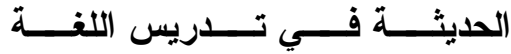

العربية"الأسس و التطبيقات". عدــان:

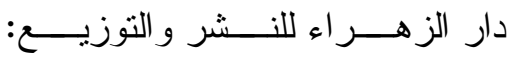

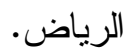

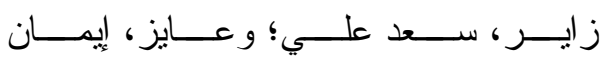

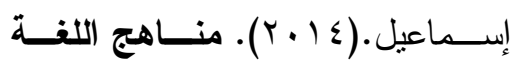

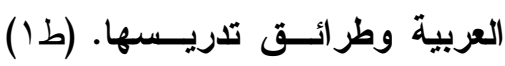

عمّان: دار صفاء للنشر و التوزيع. تلعزئ.

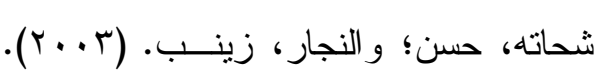

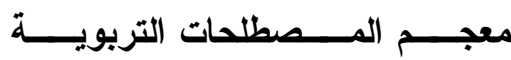

و النفسية. القاهرة: الـــدار المــصرية

اللبنانية.

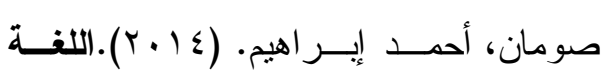

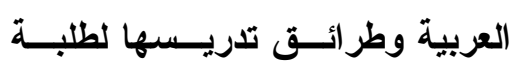

بركات، زياد أمين.(9 . . ب). دراسة تحليلية

مستعرضة للأخطاء الإملائية الثائعة

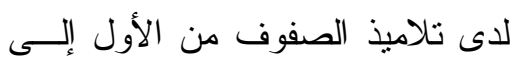

الخامس الأساسية في مدينة طــــولكرم

بفلسطين. مجلة العــــوم التربويــة، مدئه

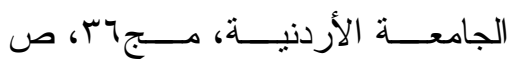

ص الـــ17

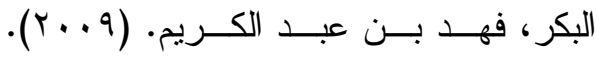

الأخطاء الإملائية الثائعة لدى طالبات

الصف الثالث المتوســط"تشخيـصها

و أسبابها". مجلة جامعة الإمام، رجب

.111

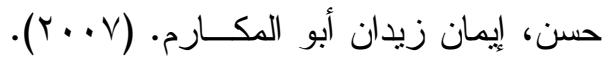

فعالية برنامج مقترح في علاج بعض ريل المان

الصعوبات الإملائية لاى الدارسـين برين

بمعه البحوث الإسلامية من الناطقين

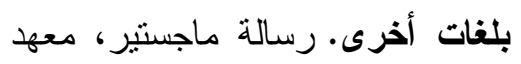

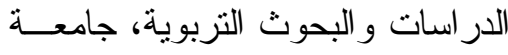

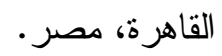

الحلاق، علي سامي.(ع ا • ب). المرجع فــي

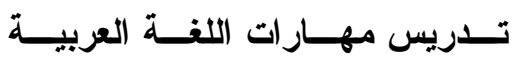

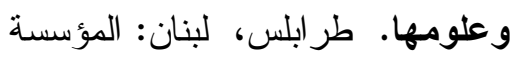

الحديثة للكتاب.

الخليفة، حسن جعفر ؛ ومطاوع، ضياء الدين

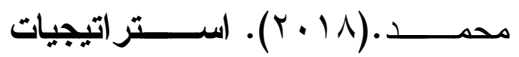




$$
\begin{aligned}
& \text { دليل المعلم و المشرف التربوي ودليل } \\
& \text { التربية العملية للطلاب. } \\
& \text { عو اد، فردوس إسماعيل.(r ( ب). الأخطاء }
\end{aligned}
$$

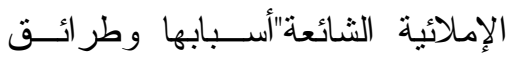

$$
\begin{aligned}
& \text { علاجها". مجلة الدراسات التربويــة، }
\end{aligned}
$$

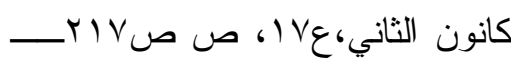

$$
\begin{aligned}
& \text {.ro. } \\
& \text { فضل الله، محمد رجب.(ع ا • r). المرجـع } \\
& \text { في تدريس اللغة العربيــة بــالتعليم } \\
& \text { الأساسي. القاهرة: عالم الكتب. }
\end{aligned}
$$

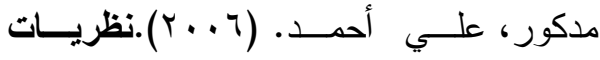

$$
\begin{aligned}
& \text { المناهج التريوية.(ط؛) القاهرة: دار }
\end{aligned}
$$

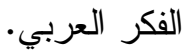

$$
\begin{aligned}
& \text { المعايطة، آلاء زيد عبد الحميد؛ وأبوي أمين }
\end{aligned}
$$

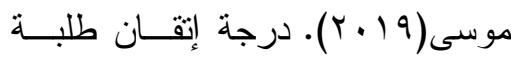

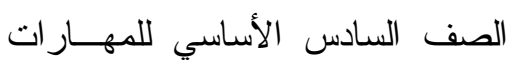

$$
\begin{aligned}
& \text { الإملائية في اللغة العربية في ضـــوء الاسية }
\end{aligned}
$$

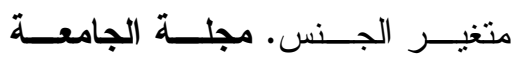

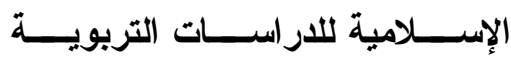

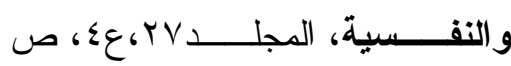

$$
\begin{aligned}
& \text { ص }
\end{aligned}
$$

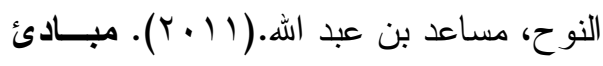

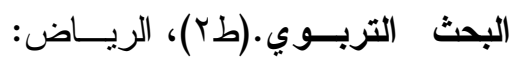

$$
\begin{aligned}
& \text { مكتبة الرشد - ماثشرون. }
\end{aligned}
$$

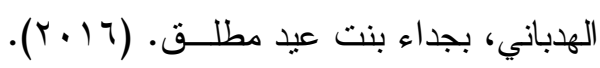

$$
\begin{aligned}
& \text { المرحلة الأساسية الأولى. عمّان: دار } \\
& \text { كنوز المعرفة العلمية للنشر و التوزيع. } \\
& \text { الصيني، عثمان محمود.(ي } 99 \text { ()). الأخطـــاء }
\end{aligned}
$$

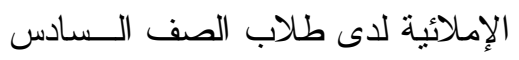

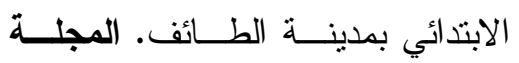

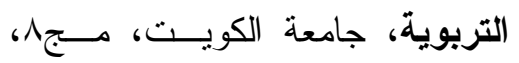

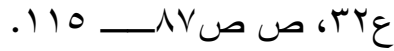

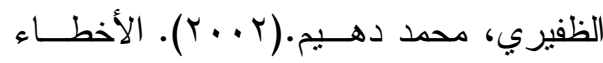

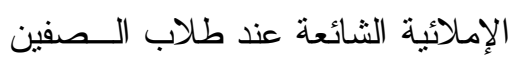

$$
\begin{aligned}
& \text { الثالث و الر ابع من المرحلة المتوسطة }
\end{aligned}
$$

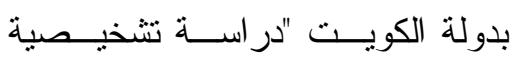

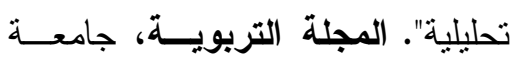

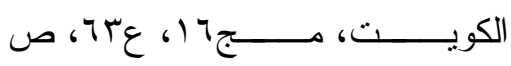

$$
\begin{aligned}
& \text { ص صr } \\
& \text { عاشور ، راتب محمد قاسم.(1) • ب). مستوى }
\end{aligned}
$$

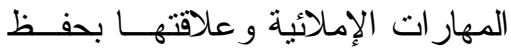

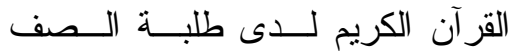

$$
\begin{aligned}
& \text { السادس الأساسي في محافظة إربـــــ } \\
& \text { مجلــة جامعــة القـــس المفتوحسـة } \\
& \text { للبحـــوث الإنــــاتية والاجتماعيــة، } \\
& \text { جامعة القدس المفتوحة، تموز 11 ــr، } \\
& \text { ع ع r. }
\end{aligned}
$$

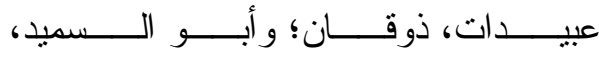

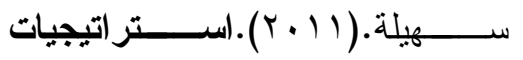

$$
\begin{aligned}
& \text { التدريس في القرن الحادي والعشرين }
\end{aligned}
$$




$$
\begin{aligned}
& \text { (كتــاب المعلــم). (ط ا)، الريــاض: } \\
& \text { مطابع العطار - م } \\
& \text { (ب) المراجع الأجنبية: }
\end{aligned}
$$

Fritz, c.o. and Morris,P.E.(2012). Effect Size Estimates: Current Use, Calculations, and Interpretation. American Psychological Association, Journal of Experimental Psychology: General, vol.(141),No. (1),pp:2-18 .

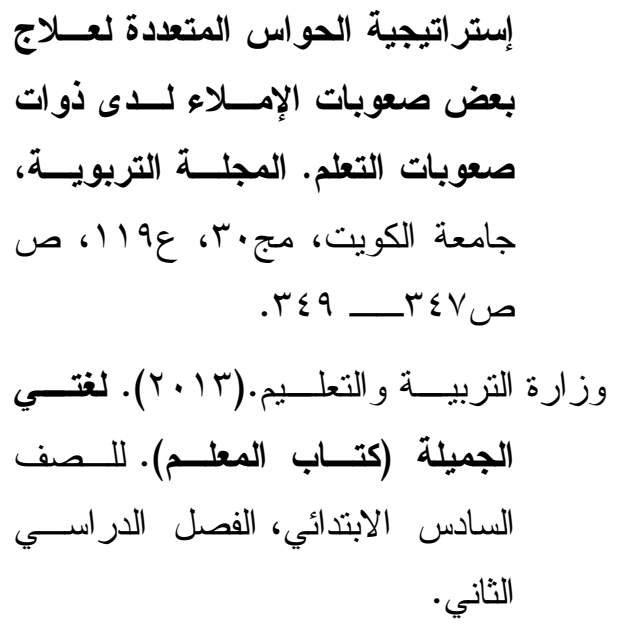

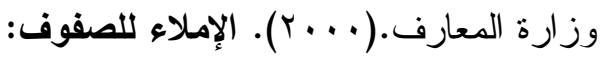

الرابع والخامس والسادس الابتدائية 